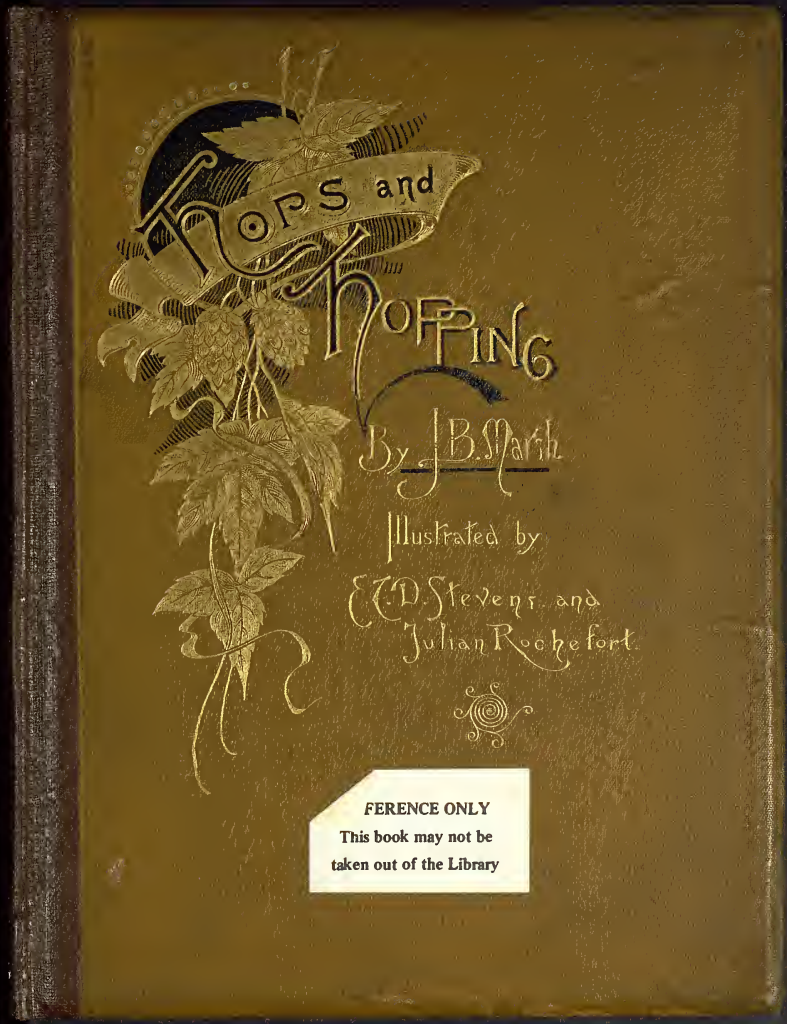




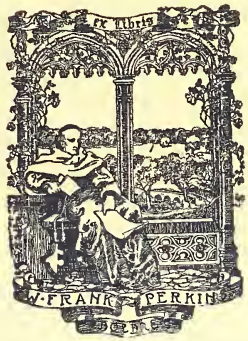

SOUTHAMPTON

UNIVERSITY LIBRARY

\begin{tabular}{|c|c|}
\hline BOOK NUMBER & $50-57146$ \\
\hline CLASS MARK & 19.1 \\
\hline
\end{tabular}




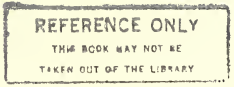




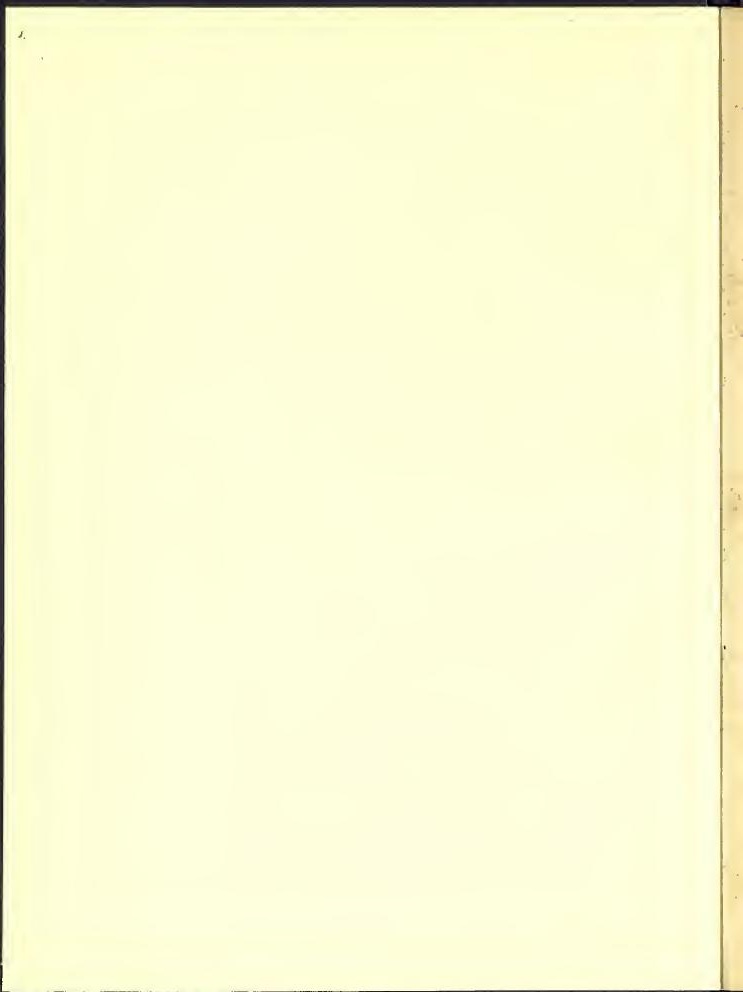


Hops AND Hopping. 


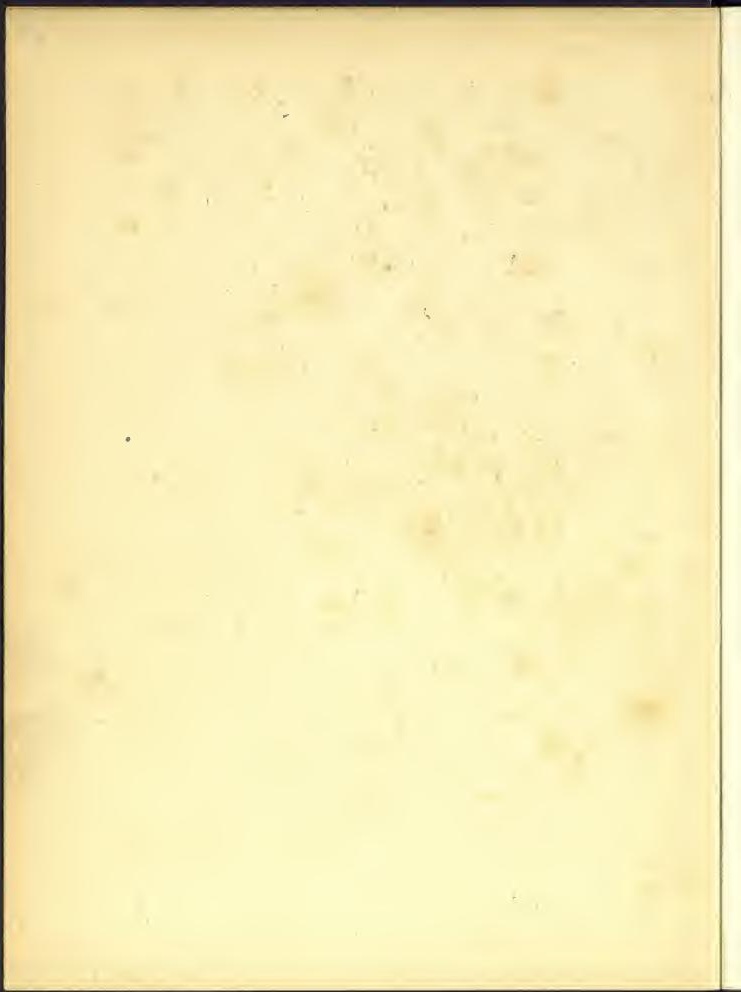




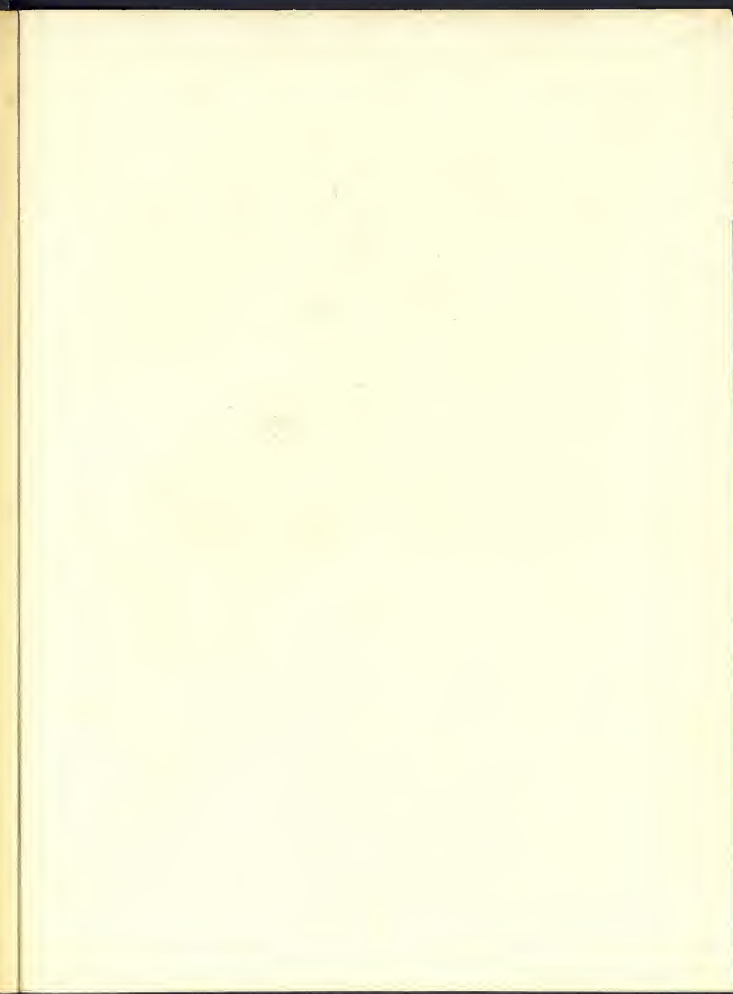




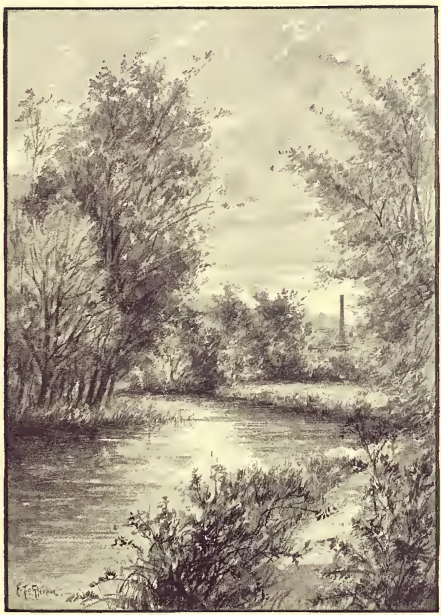

The Medway, Near Farleigh 


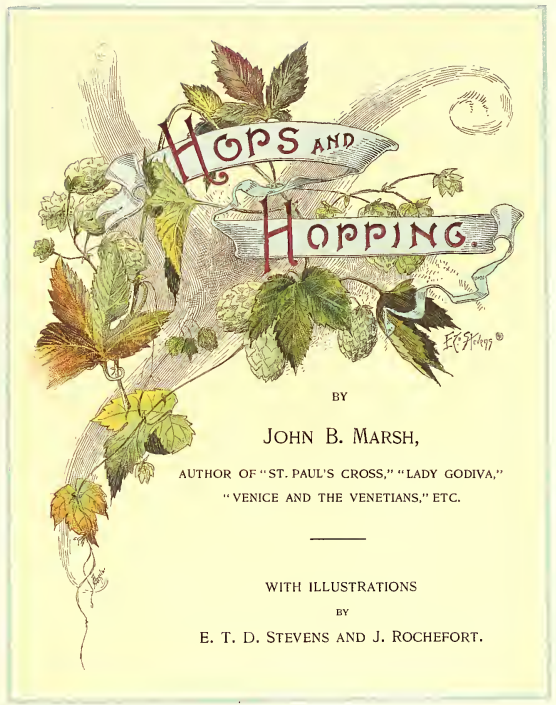




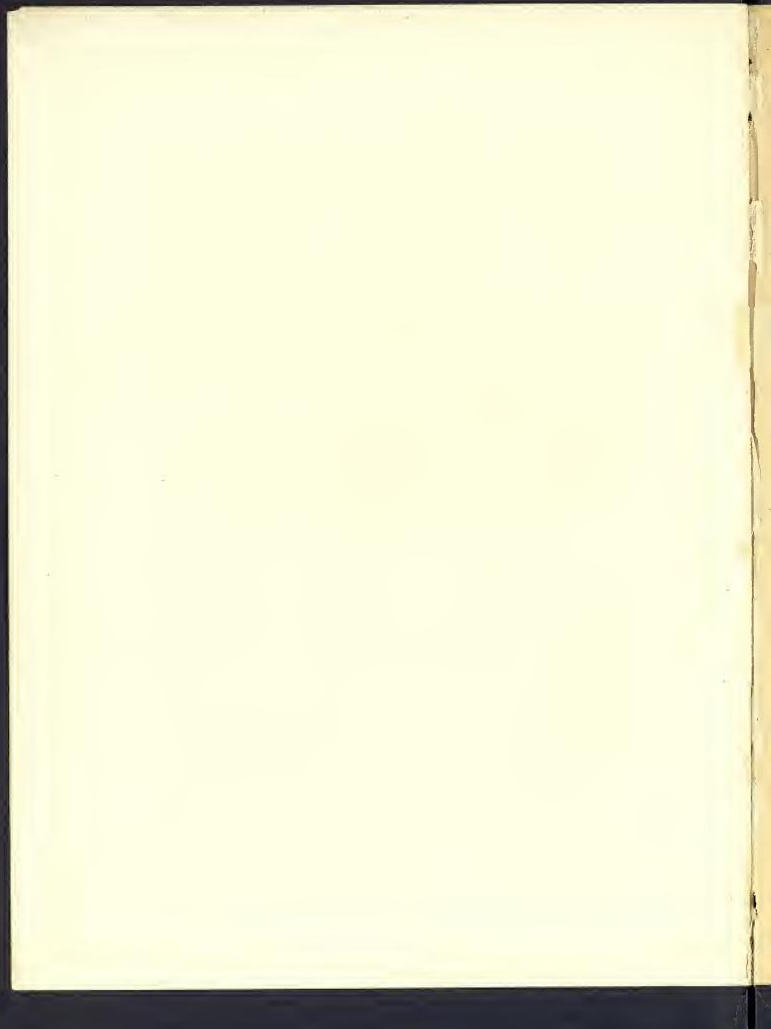




\title{
HOPS AND HOPPING
}

\author{
BY \\ JOHN B. MARSH, \\ AUTHOR OF "ST. PAUL'S CROSS," "LADY GODIVA," \\ "VENICE AND THE VENETIANS," ETC. \\ WITH ILLUSTRATIONS \\ BY \\ E. T. D. STEVENS AND J. ROCHEFORT.
}

\section{LONDON :}

SIMPKIN, MARSHALL, HAMILTON, KENT \& CO., LIMITED.

RAITHBY, LAWRENCE \& CO., LTD., I IMPERIAl BUILDINGs, Ludgate CIRCUS, E.C.

Leicester : De Montfort Press, Queen Street.

1892. 


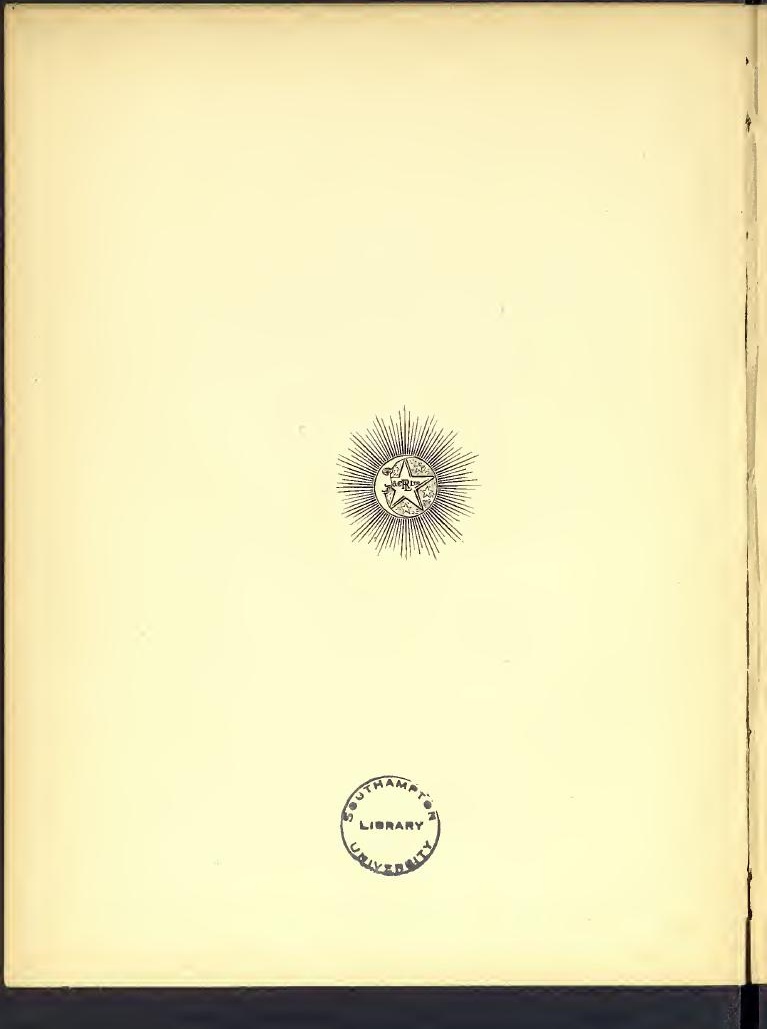




\section{CONTẸNTS.}

\section{PART I.}

The Garden of the World-Acreage under Hops-The Land and the Labour-Maidstone-Historical Notes-Views in Maidstone-All Saints' Church-Old Palace-The Cliff-Old College-The BridgeAllington-The Castle-The Loose Valley-Aylesford Bridge and Kit's Coty House-The Friars-East Farleigh Bridge-HollingbourneLenham and Ightham-House from Birkett's Meadow-Bits on the Medrvay.

\section{PART II.}

Cultivation of the Hop- "An Unwholesome Weed" - Cast of Planting -Employment of Labour-Kent Parasites-Training the Hops-The Espalier Method-Enemies of the Hop-Great Profits.

\section{PART III.}

The Hoppers-East and West take a Holiday-The Provident and Improvident-The Invasion of Kent-Probable Number of HoppersCost of Picking-The Functions of a Binman-A Measurer and a Booker-Hop Huts-The Rules-Pickers at Work-Oast Houses-Mode of Travel to the Hop Gardens-Rail and Road-The Children at Work-The Terrible Insects-The Widow's Pocket-Sunday amongst the Hoppers-Their Horror of Dogs and Darkness-How they LiveThe Costermongers-Earnings, of the Hoppers-Philanthropy at Work -The Drowned Gipsies-The Cholera Visitation-Biddy's Return. 


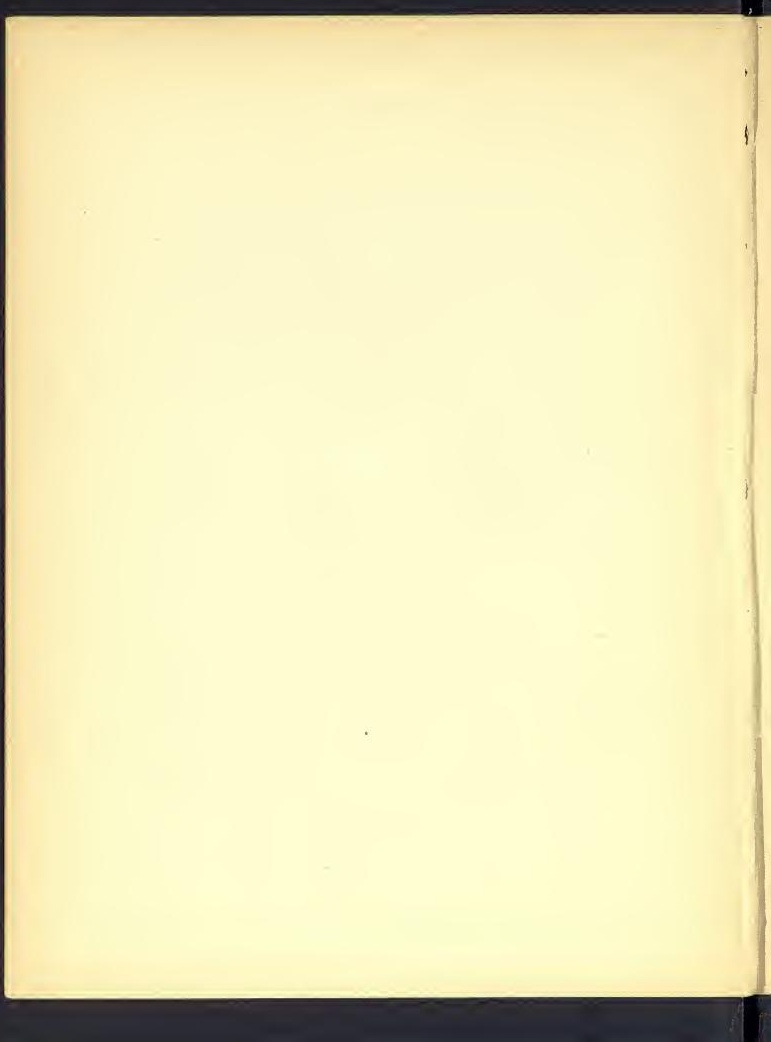




\section{LIST OF ILLUSTRATIONS.}

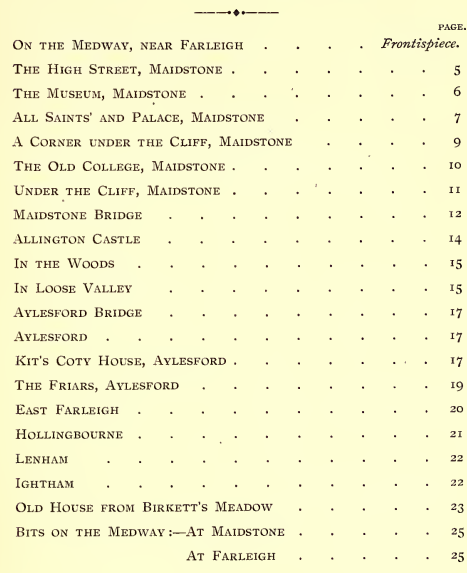


ON the River at Allington . + . . + . $3^{1}$

Hops Growing on Wire . . . . . . . . 34

Hops Growing on Poles . . . . . . . 34

A Hop Garden in Winter . . . . . . . 37

People you may Meet . . . . . . . . . 43

In THE Hop GARDEN . . . . . . . . . 49

Hoppers Preparing Supper . . . . . . . . 5 I

OAst Houses at Tovil . . . . . . . . . 53

PUtTing ON THE BRimstone . . . . . . . 54

Hop-Pickers leaving London Slums * $\cdot$ * * $\quad 55$

POOR HOP-Pickers oN THE ROAD . . . . . 57

The Famly Umbrella . . . . . . . . 58

QueEN of The Hop Garden . . . . . . . 59

Widow Hannagan's "Big Pocket". . . . . . 6i

OAst Houses at Farleigh . . * * * . . . 65

Monument in Hadlow Churchyard:-"The Grave of the

DROWNED HOP-PICKER" . . . . . . . 75

Graves of the Hoppers who died of Cholera at East

FARLEIGH . . . . . . . . . 77

Hartlake BRidge . . . . . . . . . 77

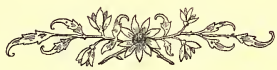




\section{PREFACE.}

THE notes which form the basis of the following pages were made during a Hopping frolic, at Yalding, when, with my wife and daughter, I spent a holiday "Hopping." We never enjoyed an outing half as much, and earned quite a respectable sum of money.

I am indebted to Mr. and Mrs. Mark, of Yalding Hill, and to Mr. and Mrs. Everest, of Yalding, Kent, for many details of life amongst the Hoppers; and still further owe much to zealous workers amongst the Hoppers, for facts, but these friends absolutely refuse to allow me to mention their names.

I am delighted to be associated, in the preparation of this work, with so promising a young artist as $\mathrm{Mr}$. Stevens, a Kent man, whose dainty sketches first suggested the book, and with Mr. Julian Rocherort, whose studies of life have made him famous.

THE RED HOUSE,

JOHN B. MARSH.

ST. ANN'S HILL,

WANDSWORTH,

LONDON. 


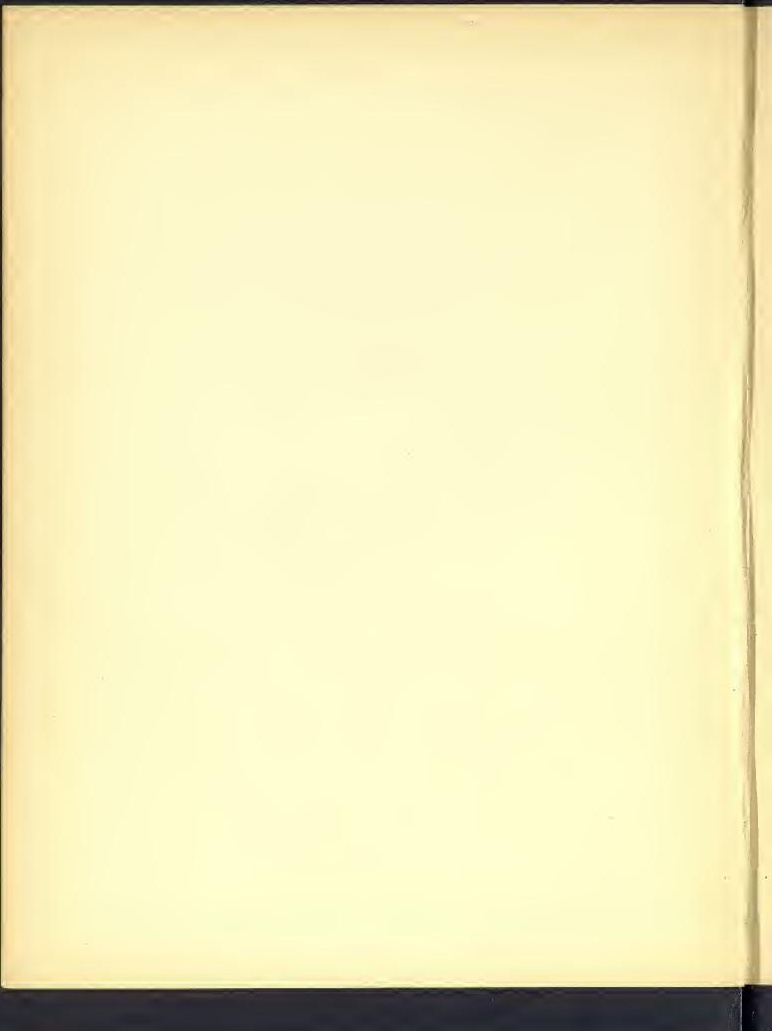


PART I.

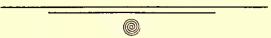




\section{SPRING.}

Birds' love and birds' song

Flying here and there,

Birds' song and birds' love,

And you with gold for hair;

Birds' song and birds' love,

Passing with the weather;

Men's song and men's love,

To love once and for ever.

Men's love and birds' love,

And women's love and men's;

And you my wren with a crown of gold,

You my queen of the wrens;

You the queen of the wrens-

We'll be birds of a feather,

I'll be king of the queen of the wrens,

And all in a nest together.

TENNYSON. 


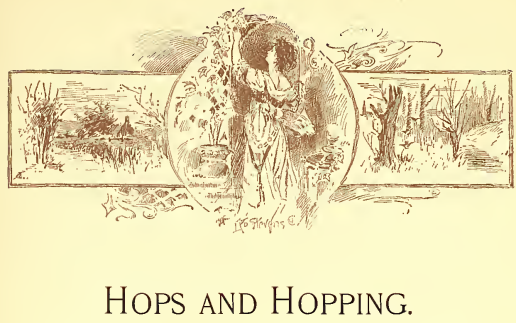

PART I.

The Garden of the World - Acreage under Hops-The Land and the LabourMaidstone-Historical Notes-Views in Maidstone-All Saints' Church-Old Palace-The Cliff-Old College-The Bridge-Allington-The Castle-The Loose Valley-Aylesford Bridge and Kit's Coty House-The Friars-East Farleigh Bridge-Hollingboume-Lenham and Ightham-Old House from Birkett's Meadow-Bits on the Medway.

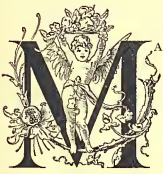

AIDSTONE is planted in the very heart of the garden of the world; for nowhere else under the sun, is the land more prolific, bringing forth crops as though Jupiter himself showered gold from heaven into the lap of a Kentish Danae every harvest time. No other English county offers a more charming variety of scenery, of hills and valleys, woods, meadows, fruit orchards, hop gardens, and rivers, presenting, 
as they do, an unending succession of scenes of natural beauty. Our artists have not been slow to acknowledge the attractions of the county; while the poor of London look to the hop harvest as the Canaan of their year's wanderings. Out of 57,724 acres of ground devoted to the cultivation of the hop in England in $1889,35,487$ acres were in Kent, and nowhere on the Continent, in the United States, or in the Colonies are hops brought to greater perfection. When the "Hop Industry" Committee of the House of Commons was sitting, Mr. Burnett Tabrum, a hop merchant, produced an Oregon hop, "almost a perfect sample," worth $95 /$ a cwt. ; while an East Kent Golding which he exhibited, was worth $126 / \sim$ a cwt.

No other branch of agriculture gives anything like the same amount of employment as the cultivation of the hop. The planting of an acre of "the wicked weed" costs $£ 44$ I8s.; after this the yearly outlay is $E_{40} 5 \mathrm{~s}$.; and of these sums $E_{17}$ per acre goes in labour alone. Thus growers estimate that every three acres of hops will maintain a labourer; while from 50 to 60 acres of pasture land are required to keep a labourer constantly employed. The average yield of hop fruit is ro cwt. to the acre. In 1882 Kent hops realised the abnormal price of $£ 3$ o a cwt.

But the crop is one over which the grower has no control. The most skilful man frequently fails to secure one worth picking, while at other times the yield would be worth thousands of pounds. One instance is recorded of 60 acres producing $£$ io,ooo worth of hops; another well-known case was that of 28 acres of ground which produced $\mathcal{E}_{28} 8$ worth of hops one year, and the next season $£_{7}$ oo worth.

In the following pages the author has confined his attention more to the social questions which come to the surface at hopping time-the emigration from London; the wages earned; the 
money squandered; the character and condition of the poor hoppers; and the efforts directed to the amelioration of their condition-than to any disquisition on the important question of the hop industry. The illustrations are not to be taken as exhaustive of the character of the views in the country, but rather as a sample only, selected in Maidstone and the immediate neighbourhood.

The town of Maidstone-the county town of Kent-occupies the sloping sides of a hill which rises in the valley of the Medway. Other more lofty hills rise beyond, until a table-land is reached of great beauty; and associated with all the historical events which have made the county famous.

On Penenden Heath, one mile from Maidstone, Lanfranc, Archbishop of Canterbury, met the brother of William the Conqueror, Odo, Earl of Kent, at a conference, to settle the serious differences which had arisen between them respecting the lands of the Church seized by the Earl, and which were ordered to be restored. In Maidstone the Archbishops of Canterbury had a palace from the time of King John, Edward VI. granted the first deed of incorporation to the town, which was forfeited by the Wyatt rebellion, and only renewed after the accession of Queen Elizabeth. Three insurrections - all of them disastrous to the persons concerned-grew to a head amongst the men of Kent; these were the rebellion of Wat Tyler, the insurrection of Jack Cade, and the rising under Sir Thomas Wyatt. The streets of Maidstone echoed to the shouts of these rebels; and wives and children mourned there the execution of their misguided relatives. But all her rebellions were amply atoned by the magnificent stand made by the inhabitants in favour of Charles I.; though after many hours' hard fighting on one June night, in I648, the loyal townsfolk were utterly defeated. 
A subsequent mayor, Andrew Broughton, acted as Clerk of the Court at Westminster Hall on the trial of Charles I. Along these streets strutted Samuel Pepys, "mightily" delighted with everything he saw, on which occasion he dined at the Bell, on a dish of fresh fish, which he purchased himself; here walked William Woollett, the engraver; and during the war with France George III. came to Maidstone, and reviewed the volunteers of Kent in the Mote Park. The town now boasts a population of $30,000-$ thrifty, hard-working, happy people.

\section{High Street, Maidstone.}

This is a broad and handsome thoroughfare which ascends from the bridge. The fountain and the statue to the Queen are in the foreground; in the middle distance the old-fashioned Town Hall ; while the Kent Fire Office is on the right. Upon market day-Thursday-the street is crowded with country folk, and a capital opportunity is furnished of studying the manners and the faces of the Kentish lads and lasses. This street was the scene of an awful conflict one June evening in 1648 , when Fairfax, with his Roundheads, defeated a strong Royalist force under Sir John Mayney, the fight raging until after midnight.

\section{The Museum.}

This was formerly Chillington Manor House, which was forfeited to the Crown for the share taken by the Maplesdens in the Wyatt insurrection. Now devoted to the purposes of a museum and public library, the building is highly appreciated by the inhabitants. There is a good collection of birds and fossils found in the neighbourhood, as well as Roman remains discovered in the town. The view is taken from the gardens, which are laid out with great care and taste. 


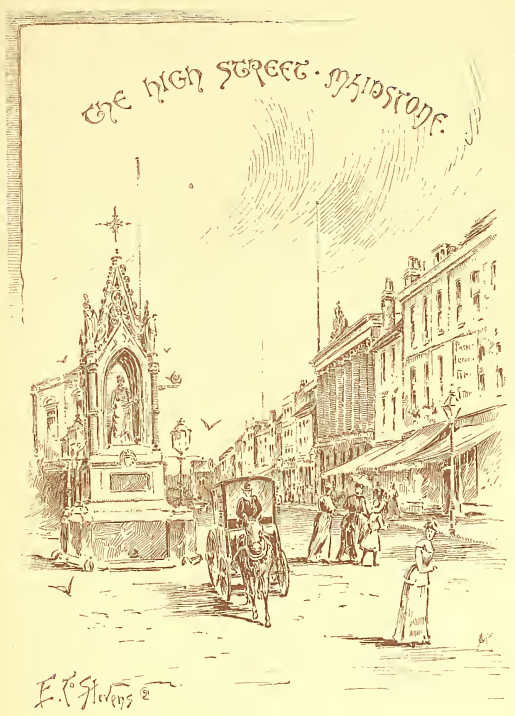


All Saints and The Palace.

Looking across the Lock meadow, now used as recreation grounds, a view is obtained of the old Palace (now the property of the town), with the church of All Saints, close beside the silvery Medway. There was a palace here in the reign of John, which was a gift to the archbishops from

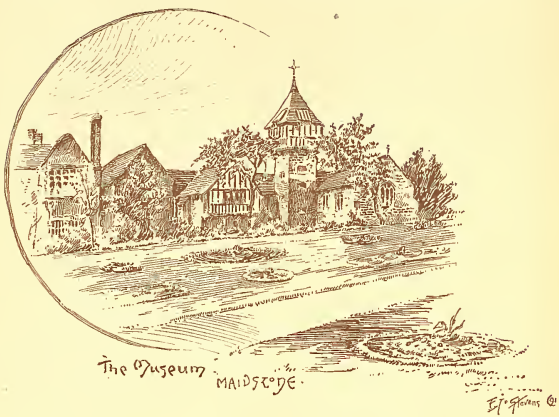

the rector of Maidstone, about 1208. Archbishop Langton was the first prelate who resided here. In 1348 Archbishop Ufford pulled down the old residence, and began building a more suitable one, which was completed by Archbishop Islip. Portions of the work done by different archbishops are still 


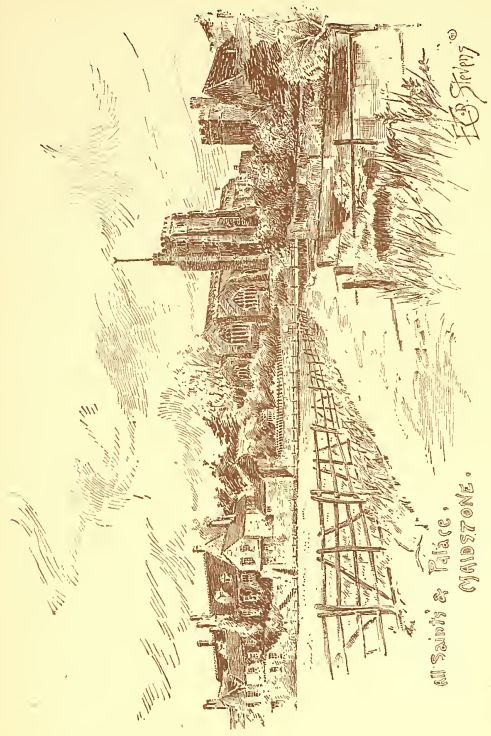


traceable in the remains. In the southern portion are the great dining room and the chief lodging chamber, now used as a drawing room. The dais on the east side of the dining room has an oak floor, and the walls are panelled in oak; above the fireplace the Astley arms are seen, carved on the oak mantelpiece. The kitchen was on the river side of the building, and contains an enormous fireplace, large enough to roast a sheep or an ox.

The church of All Saints contained twenty-eight stalls of carved oak, for the use of the members of the college, marked with the armorial bearings of Archbishop Courtenay. Here were buried Lord Rivers, father of Queen Elizabeth Woodville; John Wooton [d. I4.r7], first master of the college; William Grocyn; Sir Jacob Astley, the cavalier [d. $6_{5} \mathrm{x}$ ]; and other members of the family. There is a folio Bible and missal of the date of 1400 in the vestry library.

The Cliff, Maidstone.

The walk beside the river, under the cliff, at Maidstone is the favourite resort of lovers when in summer-time "Kent will say her Medway doth excel: when the lengthening shadows bar her pathway; when the rooks, with a warning note, seek their nests; when the drowsy kine make the valleys echo with their farewell lowing; when the barges float by with scarce a ripple on the river's bosom; and the busy insects with many a droning sound haste to flower, or leaf, or cranny for the night. The grey stones of the palace tell of centuries that have fled ; but love and hope never grow old."

The Old College, Maidstone.

These are the ruins of the Hospital or College for Poor Travellers, erected on the brink of the river, at the west 


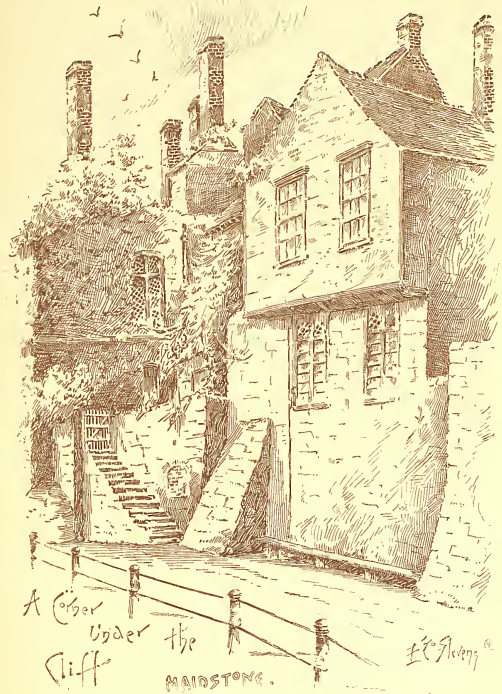


entrance to the town, by Archbishop Boniface, in 1260, and dedicated to St. Peter and St. Paul. About 140o, Archbishop Courtenay incorporated the hospital with a college for secular priests, which he had founded; and the church and college were dedicated to All Saints. The establishment flourished until suppressed by Edward VI. William Grocyn, the tutor and friend of Erasmus, was one of the masters. The remains

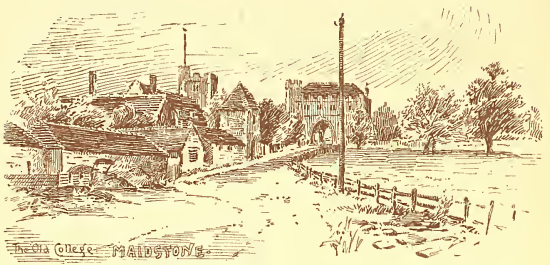

are exceedingly interesting; the gateway tower is thickly clothed with ivy, the grey stone peeping out at intervals. There is a fine view of the winding Medway and the distant hills from the walls. The range of buildings leading to the river is terminated by a tower. There is another gateway which is picturesquely set between two barns; while the remains of the refectory, kitchen, dormitories, cells, and bakehouse may be traced. What was formerly the master's house has been modernised, and is now used as a dwelling house. 

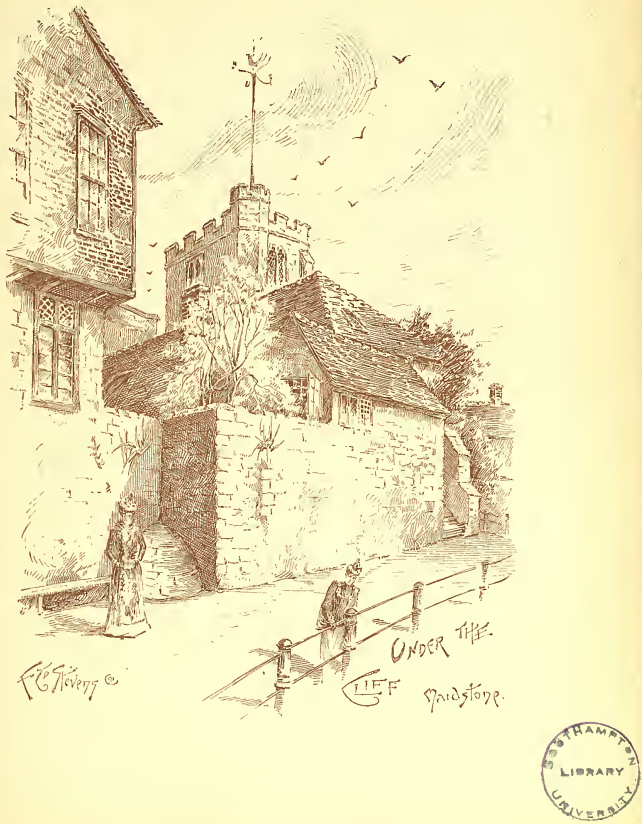


\section{UNder the Cliff, Maidstone.}

This pretty corner is also to be found under the cliff. Here again are remains of the palace, and the steps hard by up which, so the local story states, if you go twelve times in succession you will see a face bathed in blood. As a constitutional, the exercise may be commended; but no one who has tried the Midf experiment is ever recorded to have seen the face. The 5 ore ivy-clad stones mark the portion of the palace now Pridse used as a school of art and music.

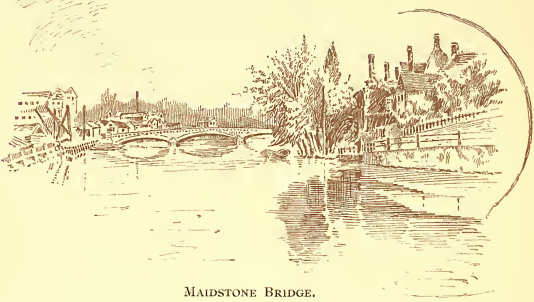

This view was sketched from the Horse Wash, and shows a portion of the old palace and cliff on the right; and the bridge in the distance, which was opened in 1879 .

Village of Allington.

This is one of the smallest and certainly the most picturesque of villages in the county; it lies on the western bank of the Medway, and is two miles from Maidstone. The bend in 
the river adds much to the beauty of the scene; and the house shown, now a private residence, was formerly the famous Gibraltar public-house. There is a belt of elms and oaks in the background, in which the voices of the sweetest singing birds never cease throughout the summer day.

\section{Allington Castle.}

The Castle of Allington was erected by Baron William de Warrenne, on the estate passing into his possession after the disgrace of Odo of Bayeux. Subsequently it passed into the hands of Sir Stephen de Pencestre, of Penshurst, constable of Dover Castle, and warden of the Cinque Ports. He obtained the permission of King Edward to erect a castle, and to fortify it. In the time of Henry VIII., the castle became the property of Sir Harry Wyatt, one of his privy councillors, and the worthy councillor was imprisoned in the tower of the castle by Richard III. While confined, a favourite cat brought him a pigeon daily, which enabled him to sustain his life ; and after his release, in every portrait which was painted the cat was represented sitting by his side. Sir Thomas Wyatt, the poet, was son of this man, and was born here in ${ }_{1} 5^{\circ} 3$. In a letter to his friend, John Poins, the poet thus describes his daily life :-

This maketh me at home to hunt and hawk;

And in foul weather at my book to sit;

In frost and snow then with my bow to stalk;

No man doth mark whereso I ride or go.

In lusty leas at liberty I walk;

And of these now I feel nor weal nor woe.

So I am here in Kent and Christendom

Among the muses, where I read and rhyme;

Where if thou list, mine own John Poins to come,

Thou shalt be judge how I do spend my time. 
Sir Thomas died of the pestilence in 1541 , while on his way to go on embassage from Henry VIII. to Charles V.

Another Sir Thomas Wyatt was the leader of the rebellion in the first year of Mary's reign, which terminated in the execution of the knight on Tower Hill, April II, I554. Queen Elizabeth afterwards bestowed the castle upon John Astley, the master of her jewels; and in 1720 the estate passed into

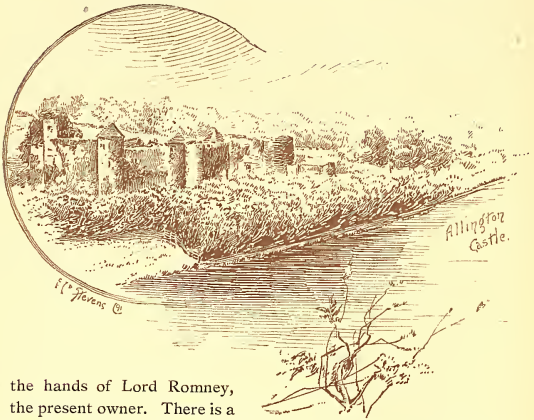
magnificent belt of trees around the ruined walls of the castle. The moat is supplied with water by the Medway, by whose stream the castle makes a conspicuous figure. The walls form a parallelogram, adorned with circular towers. There are two courts, north and south; and the principal gatehouse is 
flanked by round towers. In the south-western angle is a circular keep of very ancient date. Through one of the small towers entrance is gained to the green, before the river.

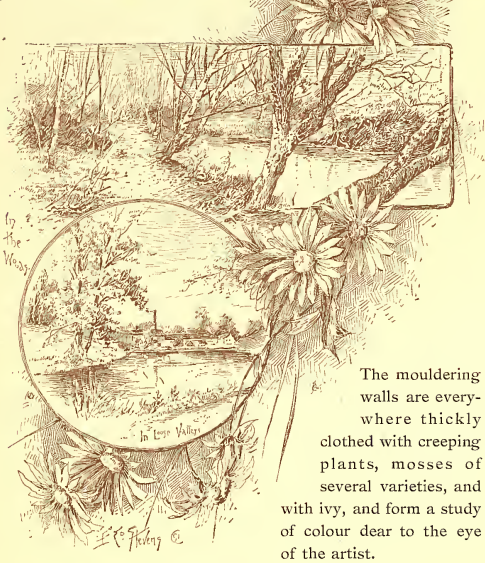


The LoOSE VALLeY-A WoOD.

The willowy hills and valleys of Loose, with the wood, three miles from Maidstone, are most celebrated and attractive spots for sylvan beauty. In the spring when the chestnut trees are in flower, the landscape glows with the pink blossoms. Here the uplands are thickly wooded, and the slow rolling streamlets are utilised to drive the ponderous wooden water-wheels of flour or paper mills. There are numerous waterfalls in the wood, whose waters, as they rush over miniature cascades, fill the air with music. The mill in the illustration is known as the Big Ivy Mill, where strawboards are manufactured; there are willow trees edging the side walk, and a well in the background with small lake in front.

\section{Aylesford Bridge and Kit's Coty House.}

The town of Aylesford is built upon the slopes of a sudden ascent, rising from the north bank of the Medway; the church stands on the summit of the bank overhanging the town. Weeping willows line the river bank with beauty in the summer time. The bridge is a picturesque feature in the landscape; the public-house shown is the George, a well-known homely hostelry. Aylesford is traditionally held to have been the scene of the battle between the Saxons, Hengist and Horsa, and the British led by Vortigern, A.D. 455, in which Horsa was killed. For many centuries a huge cairn at Horsted, three miles from Aylesford, was believed to be his burial place. There are many similar sepulchral mounds in the vicinity ; and one of the most remarkable [shown in the illustration] is Kit's Coty House. This is a massive stone dolmen; the two sides measure 7 feet by $7 \frac{1}{2}$ feet, and 8 feet by $8 \frac{1}{2}$ feet ; and they weigh 8 tons and $8 \frac{1}{2}$ tons respectively. The flat stone which forms the roof 


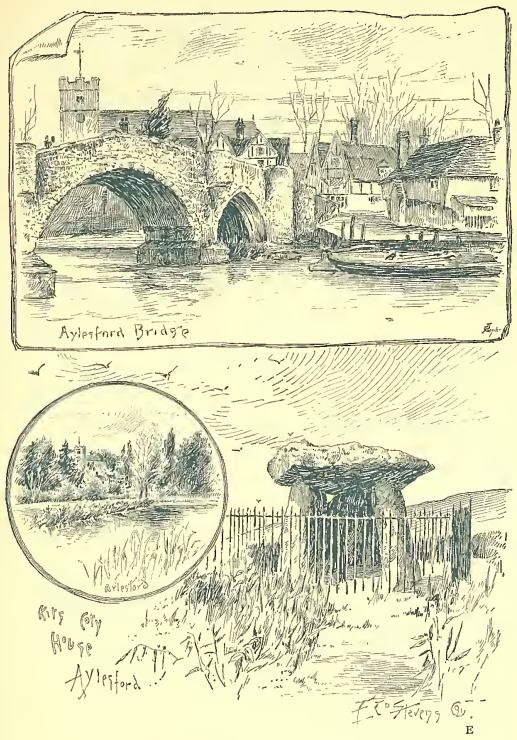


measures I 2 feet by $9 \frac{1}{4}$ feet, is $2 \frac{1}{2}$ feet in thickness, and weighs Io $\frac{1}{2}$ tons. In a field below this dolmen is a group of colossal stones, which are locally known as the "Countless Stones."

The Friars, Aylesford,

A short distance from Aylesford, on the bank of the Medway, stands the Friary, now the residence of Lady Aylesford. This was the first friary of Carmelite monks established in England, in 1240 ; and many portions of the ancient building still remain. The coming of the Carmelites is said to have been foretold by Simon Stock, a hermit (afterwards General of the order), who dwelt for sixty-eight years in a hollow oak tree, living upon water and wild fruits. The modern house is greatly indebted to the taste of Sir John Banks for the additions and alterations which make it one of the most convenient and pleasant of modern residences. The ancient chapel is that portion of the present building which stands due east and west; and the foundations of the refectory may be traced on the left hand of the inner court. The friary was bestowed by Henry VIII. on Sir Thomas Wyatt, Anne Boleyn's lover ; afterwards Queen Elizabeth granted the house and lands to John Sedley, of Southfleet; his brother inherited the property, and here was born Charles Sedley, the poet of Charles II. time. From the Sedleys the property passed to Sir Peter Ricaut, and from him to the Bankses, thence by marriage to Lord Chancellor Finch, Baron Southampton, and Earl of Aylesford. The fine old firs, walnuts, and oak trees make an effective background.

East Farleigh Bridge.

From the stone bridge of East Farleigh, with the four pointed arches-crossing the gleaming Medway-you see, surrounded with hop gardens, the ancient church only recently re-opened, 
after extensive alterations, by the Archbishop of Canterbury. The church, which is of the decorated order of architecture, appears to rise out of a bed of foliage. In this quiet nook the great Wilberforce spent a large portion of the latter years of 
squalor and vulgar dissipation; the howls of the Hopper frighten away the quiet of the day and night, and his uncouth habits startle propriety from the pretty water-side paths. As Sunday is their only day of leisure so it is made the occasion for many abominable practices. "At the bridge," says a magazine writer, "some are washing clothes: women, and girls, and boys, wild, ragged, uncouth wretches, most of them standing barelegged

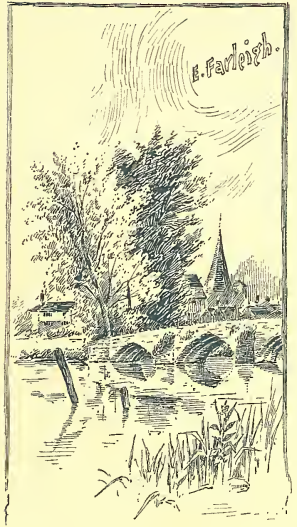
in the water, rinsing shirts in saucepans, and dabbing them against the smutty edges as fast as they are cleaned; boiling other clothes in cauldrons, and hanging garments that have more superficies of hole than cotton, upon the hedges. There, too, are hideous old Sycoraxes smoking and crouching over fires this warm day, and shouting unintelligible sounds to fat children, sprawling in the mud upon the shelving bank of the river." There is a fine walnut tree just over the bridge and the lock house. Here, just beside the locks, good-sized jacks are frequently caught by the villagers; but the Hoppers fish for the same in vain. 


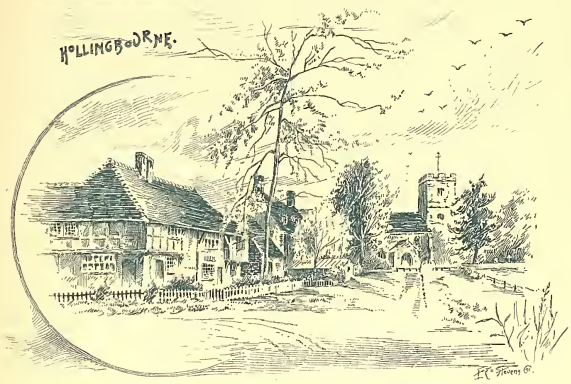

HoLLingBourne.

The pretty little village of Hollingbourne is five miles from Maidstone on the road to Ashford. It takes the name from a branch of the Hollingas and Bourne rivulets, which rising near the village form the river Len. The church of All Saints has north and south aisles, nave, chancel, and a square tower at the west end. Here lie many members of the Culpeper family, and notably the Lady Elizabeth, whose death in 1638 , common report attributes to blood poisoning caused by a prick of a needle while finishing a communion cloth about one o'clock on a Sunday morning, which she was anxious should be used in the services of that day. The old inn at the left corner is the Six Bells; and opposite is a remarkably fine old fir tree, of grotesque shape. 


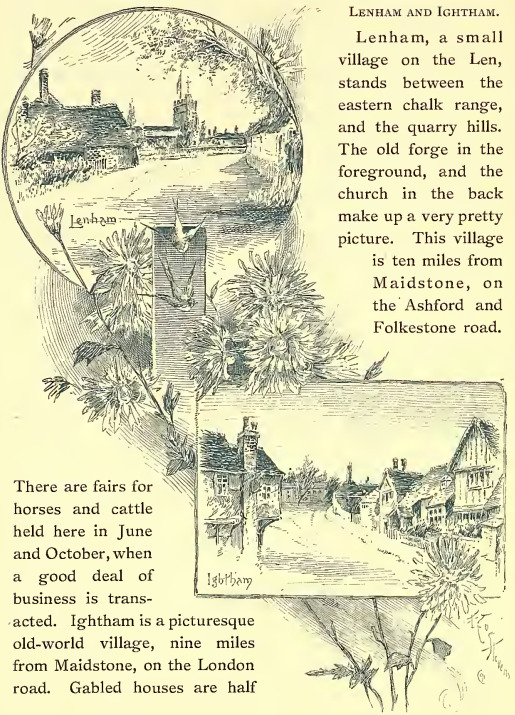


hidden amongst the trees; and the old posting-house to the left is a genuine relic of a bygone age of pleasant hostelries.

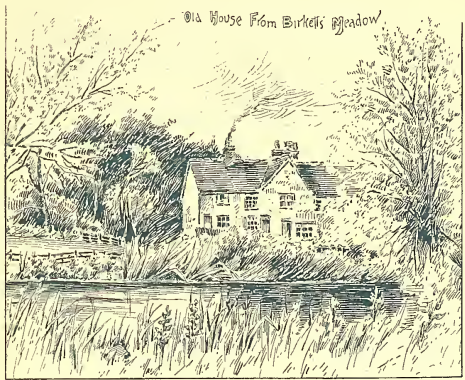

Old House from Birkett's Mradow.

A pretty study of an old Kentish cottage, with the river Len flowing in front.

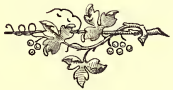




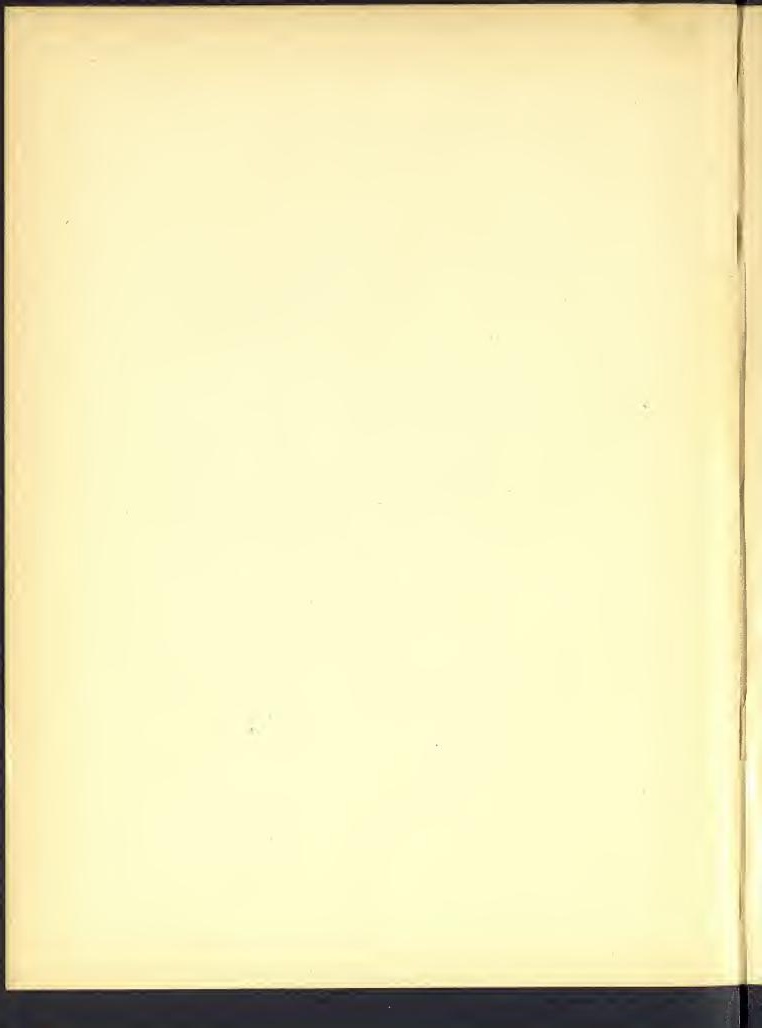




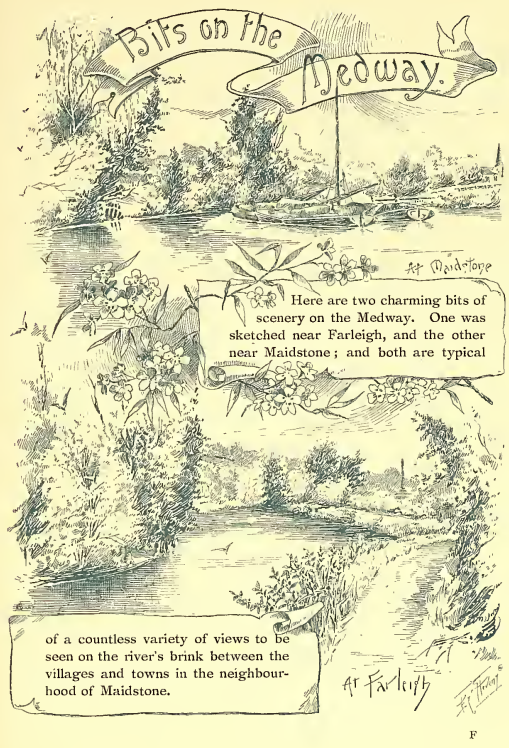




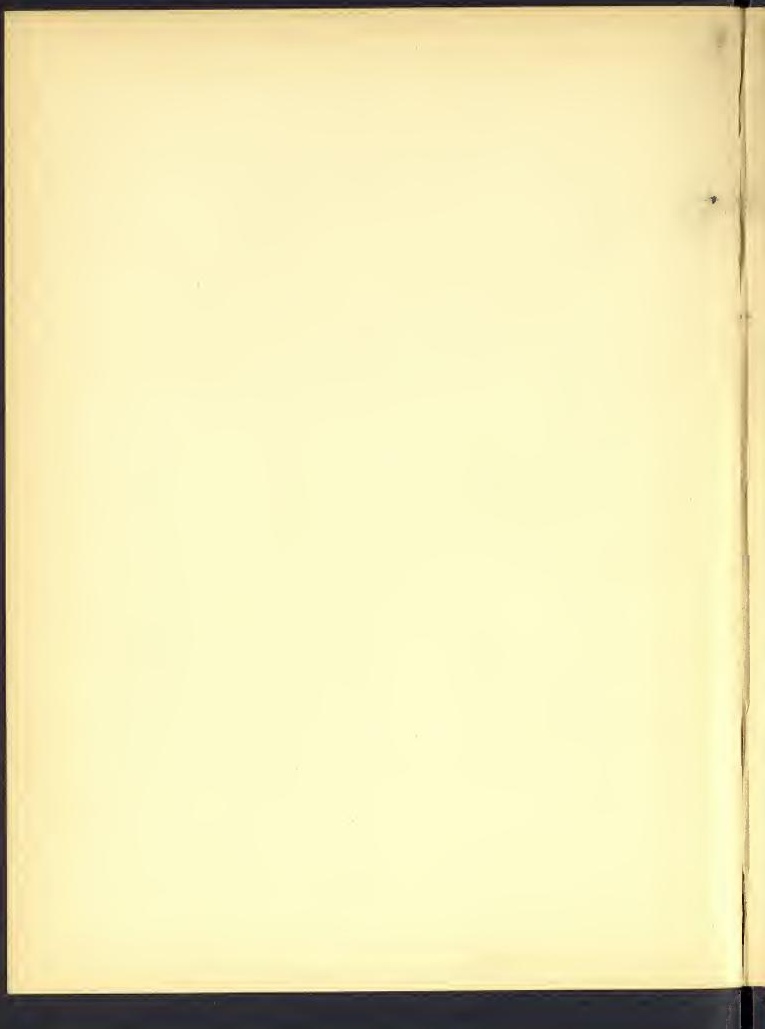


PART II. 


\section{SUMMER.}

Bright Summer comes along the sky, And paints the glowing year;

Where'er we turn the raptured eye

Her splendid tints appear.

When morn, with rosy fingers fair,

Her golden journey takes;

When freshening zephyrs fan the air, And animation wakes;

When noon averts his radiant face, And shoots his piercing eye;

And eve, with modest, measured pace, Steps up the western sky.

Thus when so fit to lift the song To gratitude and heaven, To whom her purple charms belong, By whom those charms are given?

LEIGH HUNT. 


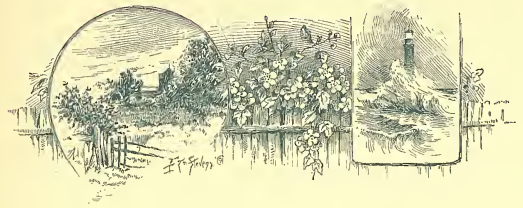

\section{Hops And Hopping.}

PART II.

Cultivation of the Hop- "An Unwholesome Weed"-Cost of PlantingEmployment of Labour-Kent Parasites-Training the Hops-The Espalier Method-Enemies of the Hop-Great Profits.

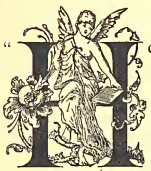

op (Humulus lupulus)," says the botanist, "is a perennial diceious plant of the natural order Cannabinacec, the only species of its genus. It has long rough twining stems, and stalked three-five-lobed rough leaves, and is a plant of luxuriant growth and abundant foliage. The male flowers grow in loose branching axillary panicles, and consist of five stamens surrounded by five-lobed perianth. The female flowers are in strobiles, or cones, with large, persistent, concave, entire scales, which enlarge as the fruit ripens. The 
part of the hop so much used in brewing, and sold under the name of hops, is the ripened cone of the female plant. Female plants alone, therefore, are cultivated to any considerable extent, it being enough if a few male plants are scattered over a field."

The hop plant was first introduced into Kent in the reign of Henry VIII., and for a long time the growth of the plant met with violent opposition. In 1426 there is a record of an information having been laid against a person for using in the manufacture of beer "an unwholesome weed called an hopp." Not long afterwards petitions were presented to Parliament against the use of "that wicked weed called hops." In $\mathbf{I}^{24}$ Parliament passed a law forbidding the use of hops, on the ground that they tended to "make people melancholy." About the year ${ }^{5} 554$ the cultivation of hops was sanctioned by Parliament, and hop farming gradually came to be recognised as one of the most important departments of agriculture.

Asked to describe to the Committee on the Hop Industry the whole operation involved, from first planting down to the selling of the bales of hops, Mr. James Selmes, a Kent hop-grower, replied in the following terms: "In the first place, if you are going to plant an acre of hops, the ploughing costs you $£ \mathrm{I}$, the harrowing $5 /-$ an acre, the setting out of plants $12 /-$ an acre, the planting $30 /-$ an acre, the hop sets (that is the cuttings which you put in to raise the plants from) $£_{5} 8 \mathrm{~s}$. Those are cuttings put in the year before to take root. Then the manure would cost $£_{2}$ ros., and another species of manure is generally used, namely, rape-cake, that would be $£_{3}$; the chopping of those hops round the hills, $6 /-$; the stakes put up, 12/-; the tying, $1 /-$; the stroking out of the furrows to let off the water, $5 /-$; the rent and rates, including the extraordinary tithe redeemed, $\mathcal{E}_{2}$; the 


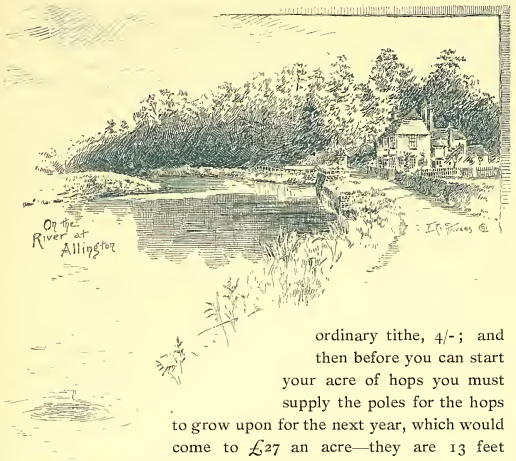

poles : three poles to the hill, that would be $\mathrm{I}, 200$ hills, or 3,600 poles to the acre, at ${ }_{15} /$ - per hundred, making $£ 27$; that makes up a total of $£ 44$ I 8s. I have only got so far as the first year's planting, upon which you get no picking. Then as regards the second year; first of all, there would be roo loads of dung per acre, and spreading, which would be $£ \mathrm{I} 2$ ros.; digging, $\mathrm{I} / 4$; dressing, 6/-; carting off the cuttings, $2 / 6$; 300 new $I_{3}$ feet poles, $\mathscr{E}^{2} 5 \mathrm{~s}$. Then carting off the old poles and carting on the new, ro/-; laying out and poling, I5/-; tying, I2/-; ladder tying, Io/-; chopping, I $2 /-$; shimming (or what is called "nidgetting" 
in Kent), E2. That has to be done several times over. Then there is striking up the hops, $7 / 6$; rent and rates, $£ 2$; tithe, $4 /$; picking, drying, and packing for, say, a crop of Io cwt. per acre, EIo; carriage to London and commission on selling, $\mathscr{f}_{\mathrm{I}}$ Ios.; stripping and stacking the poles, $7 /-$. Then $I$ have put down the interest upon the first year's outlay at io per cent. upon $£ 44$ i8s., which comes to $£_{4}$ ros.; total of those items altogether comes to $E_{40} 5^{5}$. $E_{44}$ i 8 s. is the outlay upon the first year's planting, and after that the outlay would be $\mathcal{E}_{40} 5^{\mathrm{s}}$, that is the outlay for the second year. The picking would yield to cwt. per acre, but it is often very much heavier than that. The labour, that is to say, the horse labour and the manual labour, comes to something like $\mathcal{E}^{\mathrm{I}} 7$ an acre. There is no other branch of agriculture which gives employment to the same extent."

The principal hops grown in Kent are the "Golding," which require poles 16 feet in length, and fetch from $£ 6$ and $£ 7$ a cwt. to $\mathcal{E}_{12}, \mathcal{E}_{14}$, and occasionally $\mathscr{E}_{20}$ a cwt.; the "Prolific" hop, which requires a shorter pole; the "Grape" hop, which takes a I 2 feet pole, and realises from $£_{5}$ to $\mathcal{E}_{\text {ro a c cwt.; }}$ and "Jones's," which require short poles, from 8 feet to ro feet in length, and realise about $\mathcal{E}_{5}$ a cwt.

Supposing the garden to have been laid out, as described already before the House of Commons Committee; in February and March, men open the hop hills, and dig round them; the hills are poled in April; in May the tying of the bine about the poles, or string, or wire, commences; and picking commences at the end of August or the beginning of September.

Of late years string has been run from the top of one pole to another, on which the bine runs, and from half-way up one pole to the top of the next. Wire is also used instead of string in some gardens, and then the bine is stripped off, picked, and 
thrown back again to die a natural death. Then there is the Espalier system of growing hops, which is said to be the very best, but very costly, as eight acres require an expenditure of $£ 400$. The Espaliers are put on very stout poles, something like telegraph poles with three wires, one 18 inches from the ground, one 4 feet 6 inches from the ground, and the other is at the top. Instead of two poles to every hill there is one pole to every two hills of nearly the same height, and galvanised wires of five or six strands, specially prepared for the purpose, are stapled to all these poles. The advantages of the system are obvious. In the first place, at picking time it is not necessary to cut the bine as is very often done to the detriment of the plant for the next year, bleeding the hops very much, because on this system the bines are pulled down. From cocoa-nut strings specially prepared, the hops are picked and the bines thrown back and left to die a natural death, just as the foliage falls off from the forest trees. The operation of hop-tying employs a large number of people, mostly women, and consists of tying the shoots to the poles with withered rushes very loosely, so that they may climb freely ; this work is continued till the bine is at the top of the poles. As the bine grows the anxieties of the farmer multiply; besides wind and rain, there are many diseases to which it is liable, including blight, fly, and mould. When the hop is attacked by disease the plant is powdered with brimstone blown through a machine, or washed with soap and water pumped in fine sprays all over the plant. But it is equally liable to injury from high winds or excessive rains. A dense fog with hot suns would in a day or two turn the hops brown, and render the picking unprofitable. Yet, with all these risks, hop growing is regarded as well worth following; the chances of a profitable crop are so many. 


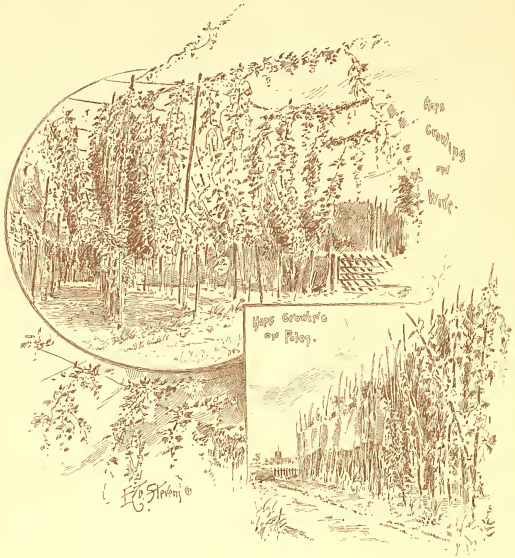

A Windy Corner in a Garden.

Here is an illustration of the old method of growing the hops on poles. This is a windy corner, and sacking has been stretched from pole to pole, to prevent the wind from damaging 
the delicate flower on the development of which so much depends. The use of wire on which to train the bine is the new method adopted by the growers.

\section{A Hop Garden in Winter.}

There is very little about the aspect of a hop garden in winter to remind one of the glories of harvest time-the picking. The poles about which the green bines have clambered, and hung in branches of green and gold, are bare enough now ; and a vivid imagination would be required to restore the poles to their proper places in the hop hills, and clothe them with the golden clusters of fruit. They hug each other now as though to find consolation in company; the heart warm enough, the outsides touched with snow ; their points occasionally serving as a perch for a singing bird, or a vantage point whence to search for a cottage window by a robin redbreast in quest of a crumb of bread. These hop poles constitute a very heavy item in the expenditure of a hop farmer, on a large garden running into thousands of pounds. In the distance is the farmer's house; and the oast houses with their great cowls, by whose kilns the hop is dried and coloured for market.

Towards the end of August the Hoppers begin to march on Kent; and their experiences, and all about them are contained in our next part.

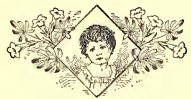




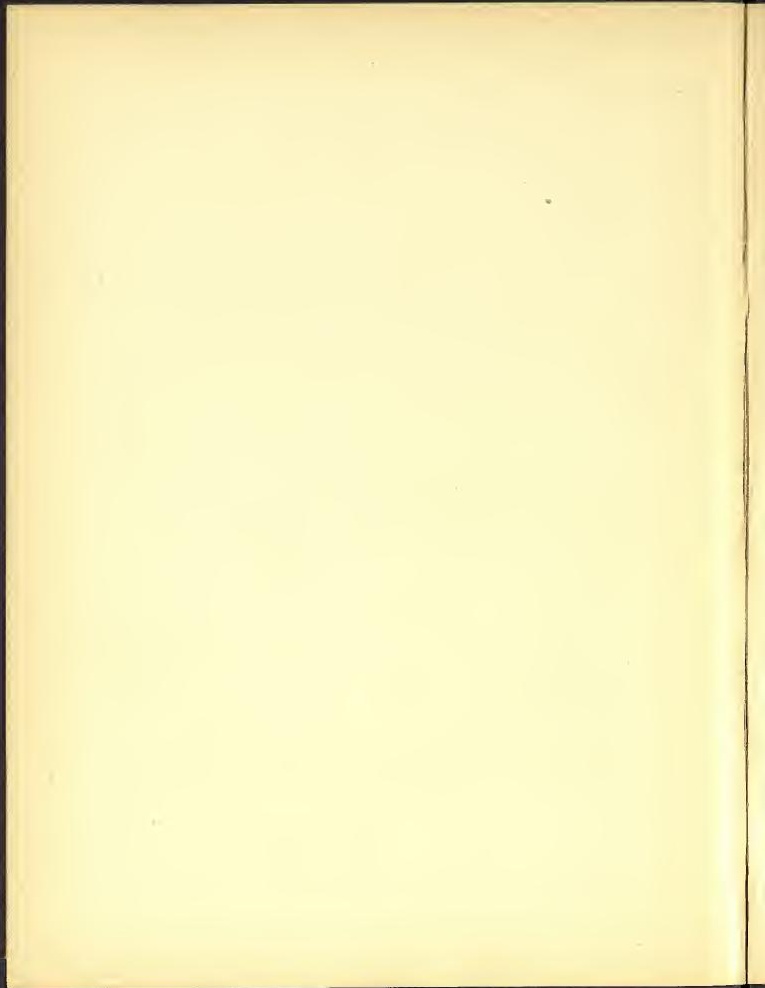




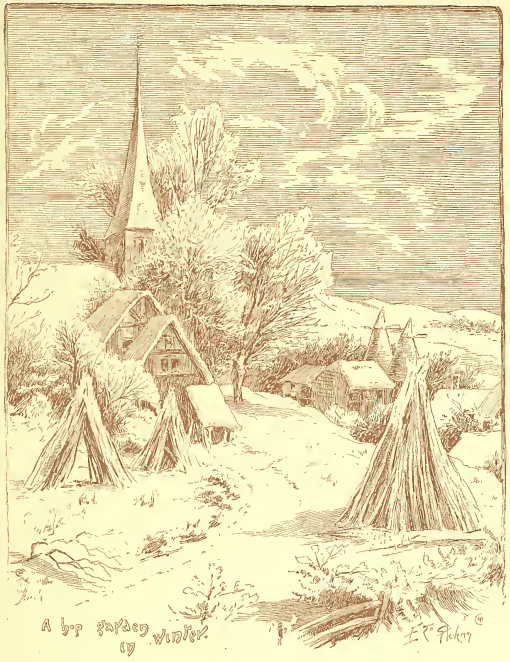




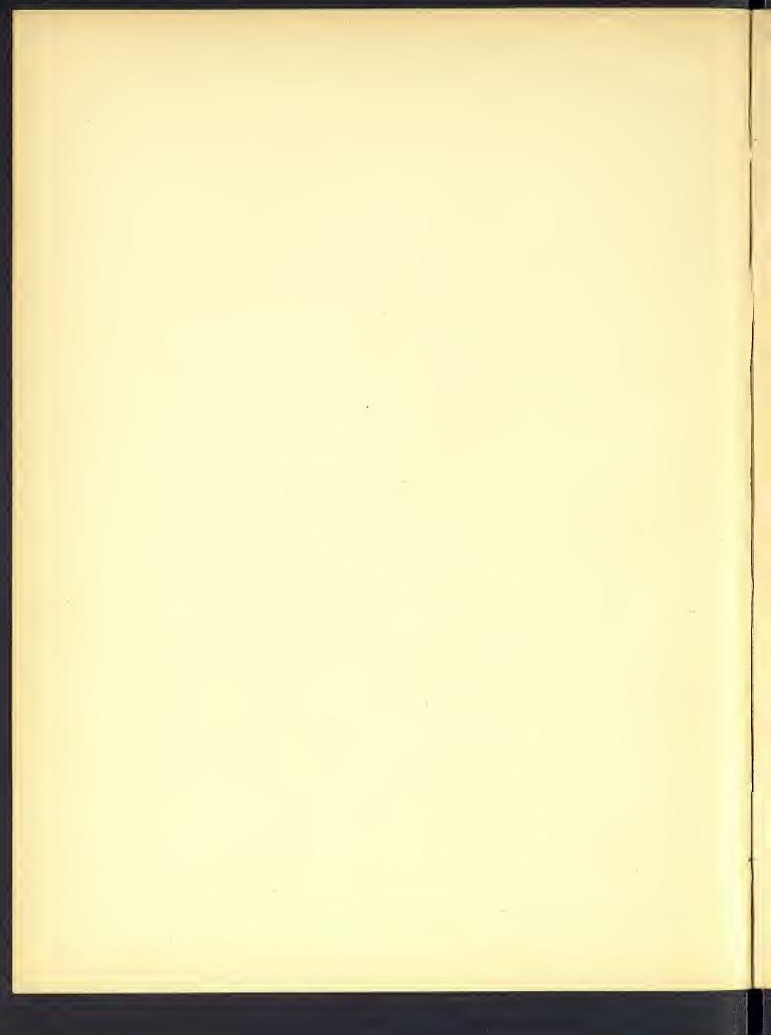


PART III.

(8) 
AUTUMN.

Season of mists and mellow fruitfulness,

Close bosom-friend of the maturing sun;

Conspiring with him how to bless

With fruit the vines that round the thatch eaves run;

To bend with apples the moss'd cottage trees,

And fill all fruit with ripeness to the core;

To swell the gourd, and plump the hazel shells

With a sweet kernel; to set budding more,

And still more, later flowers for the bees,

Until they think warm days will never cease,

For summer has o'er-brimmed their clammy cells.

Keats. 


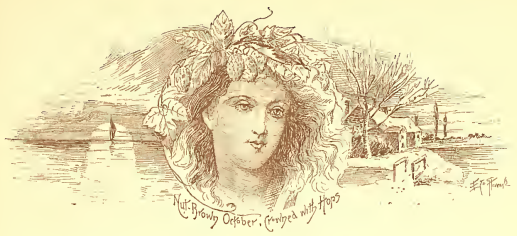

\section{Hops And Hopping.}

PART III.

The Hoppers-East and West take a Holiday-The Provident and Improvident-The Invasion of Kent-Probable Number of Hoppers-Cost of Picking - The Functions of a Binman-A Measurer and a Booker-Hop Huts -The Rules-Pichers at Work-Oast Houses-Mode of Travel to the Hop Gardens-Rail and Road-The Children at Work-The Terrible Insects-The Widow's Pocket-Sunday antongst the Hoppers-Their Horror of Dogs and Darkness-How they Live-The Costermongers-Earnings of the HoppersPhilanthropy at Work-The Drowned Gipsies-The Cholera VisitationBiddy's Return.

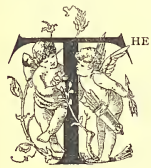

east-end and the west-end leave London about the same time of year for a summer holiday - the west-end having the start by a week or two: but they never meet outside the metropolitan area. Those in the west have an unlimited choice at home or abroad -Wales, Scotland, the Channel Islands, Ireland, France, Switzerland, or Italy, - mountain, lake, or valley; while the east find all their aspirations for change 
realised by a journey on foot, by huckster's cart, or rail to the gardens of Kent, at hop-picking time. What the banks of the Riviera are to the children of the aristocracy, the banks of the Medway and the Stour are to the children of the poor; and what the vineyards of France and Italy are to the weary votary of fashionable life, the hop-gardens are to the worn-out docker and labourer of the east of London. The one great compensation in the dreary routine of life at the docks, and in the streets of London is furnished by a month of hopping in autumn. To that period parents look forward to be enabled to pull up the lee way of spring and summer, the scarcity of work, the illnesses which have beset the family; and to make provision for that winter which always comes harshly to the poor-whether it be fine, frosty, or wet, with cold blowing winds. So the hop-garden is the promised land of the eastender's life; and when father and mother sit by cold firegrate and empty cupboard, and the children cry of hunger, they comfort one another with the words "hopping's coming." Yet the season is not always productive of the hopes set thereon; as our readers have already learned. There are greater chances against the hop turning out profitably, than of the season being a good one. But, however bad, the professional hopper makes ready for the exodus, and goes with wife and family to the gardens, where, though the returns may not equal his expectations, he enjoys a holiday and is content.

The Hopper is as variable in character as every other section of the great labour world. $\mathrm{He}$ is no more prudent, nor more improvident than the average casual labourer of the docks, the stables, the roads, the canal, or the river. When he is getting good wages he likes to eat well - and drink immoderately; when he is earning poor wages, he has to pinch himself, and loaf about with sullen heart. 


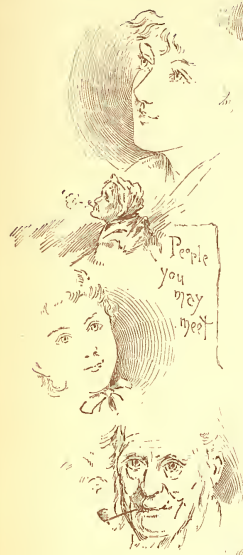

A' few years ago the Hopper was a most dangerous *. visitor-both sexes were alike feared. They were rebellious under the slightest restraints; notorious thieves; improvident in the extreme; lazy by day and riotous by night. But now, owing to the advance of education, some are of opinion-and greatly in consequence of the efforts made by Christian ladies and gentlemen, to show them the better way of life - they exhibit a degree of improvement, which is both gratifying and important. For years they were left to their own devices; and the earning of money meant only the immediate gratification of their sensual passions. They were housed in the worst possible manner; and no arrangements made for the separation of the sexes, or for observing the common decencies of life. Their condition was such that infectious diseases not infrequently broke out amongst them, and spread amongst the rural population. This was 
altered by Act of Parliament; and the owner or occupier of a hop garden now has to provide good sanitary accommodation for all the hoppers. Then the sanitary authorities appointed inspectors to see that good food was obtainable; and local societies were formed, chiefly amongst ladies who visited the women and the young girls. Schools were opened for their use in the evenings after labour was over; and finally coffeehouses were opened, where cheap wholesome refreshments were obtainable at all hours of the day. The effect has been very remarkable in the improved character of the Hoppers, and the elevation of the moral tone of their lives. This work, however, is one which requires to be renewed every season, and kept up with the utmost care and zeal: because every year a large infusion of a rowdy element mingles with the class of professional Hopper, whose character is of the worst possible descriptionabandoned, criminal, and wolfish.

All those who pick the hops are divided into two broad sections, known as the Home picker and the Stranger. The former are those who reside in the parish or the neighbourhood, or work upon the farm; while all others-no matter with what regularity they come to the same gardens to pick-are termed "Strangers."

It is with regard to these we now desire to speak. The professional Hopper acquires very much the habits of those amongst whom he works from year to year; and those most liked by the farmers are the dock labourers, who have been engaged in the great chain of docks upon the Thames. They are inured to work-in all seasons, and are reliable because of the training they have received in gang working. These men invariably bring the whole of their family with them-the wife, and five or six or more children. Each Hopper-hut will 
accommodate a family of ten; and the whole work together during the three or four weeks the picking season lasts.

The Gipsies also form a large section of workers in the hopping season, and they invariably make good workers. They reach the grounds with their own waggons, pitch their tents, and work together in companies, in which no "Stranger" is allowed to mingle. Amongst the officials of some gardens they are regarded with a considerable amount of suspicion, if not actual dislike. Besides the general reputation they have for love of .chicken and linen, they are said to be easily put out of temper, and to be revengeful, taking offence very readily with the Binman, the Measurer, or the Overseer of the ground.

All others who make their appearance in the gardens may be broadly divided into two classes - the Provident and the Improvident. The former adapt themselves to the particular circumstances in which they find themselves with good humour, are cleanly in their persons and in the use of the Hop-huts, civil to all who are about, and, above all, temperate; while the Improvident never try to make the best of their surroundings, are dirty in their habits, neglectful of common decencies, foul of speech, continually embroiled in fights, and eat and drink every shilling they earn before the hop picking has ended. To keep the peace between the rival factions of honest and dishonest, temperate and intemperate, and provident and improvident, is often a difficult task even in the hop gardens, and frequently in an evening the services of the worthy local parish constable have to be called on the side of law and order.

In order to obtain a fair estimate of what hopping time means to the people of Kent, the number of "Strangers" who invade the county at this season should be borne in mind; but an exact calculation is well nigh impossible to make; and even 
an approximate statement is liable to great variation according as the season promises well or ill for the harvest, or is fine or wet. In giving evidence before the Select Committee on the Hop Industry, in March, I890, Mr. Ambrose Warde, of West Farleigh, near Maidstone, a well-known grower, gave it as his opinion "that for hop picking alone there are at least 330 ,0oo strangers that come into the different hop picking districts every year" to pick the hops. Now there are six hop-growing counties in England-Kent, Sussex, Hereford, Hants, Worcester, and Surrey. These in 1889 had 57,564 acres growing hops; while all other counties together only had 160 acres in hops; making together 57,724 acres. These acres were distributed as follows: Kent, 35,487 acres; Sussex, 7,282 acres; Hereford, 6,850 acres; Hants, 2,905 acres; Worcester, 2,939 acres; Surrey, 2, IOI acres ; and other counties, r6o acres. Thus out of the total acreage three-fifths of the whole are in Kent; and this would mean that upwards of 150,000 "Strangers" enter Kent to pick the hops in the season, extending over from three to four weeks. Not oneseventh portion of this number travel down by rail; and where the great bulk come from is a mystery; but of this there can be no doubt, that the major portion come from near and far, forsaking for the time all other occupations, and making for the hop gardens of Kent. Very large contributions of labour are made by the poor-houses. In September, I889, Mr. Davey, the Local Government Board Inspector, made an examination of the workhouses in the Kentish Union; and he informed the Romney Marsh Guardians that the workhouses were "empty of all but very young, aged, and infirm persons," and "that there was not an able-bodied woman in any Kentish Union." Hoppicking was the simple cause of this denudation of the workhouses. While the pauper element may be said to largely mingle 
with the "Strangers" in the hop gardens, they by no means preponderate in number; their ranks are largely recruited from the tramps who from year's end to year's end infest the country roads of England-idlers and loafers, indifferently honest, and altogether lazy, who live by begging, and sleep by night in the casual ward of a workhouse or under an aromatic haystack. These men and women take to hopping as the lightest and most pleasant variation of the toil of tramping. The workhouses and the tramps contribute the most dangerous and the most disorderly section of the Hoppers, and those worst to control or to reconcile with even the light, the pleasant, and the well paid labour of hopping. All other classes of "Strangers" come under the designation of poor; and of these there are broadly marked classes. There are the poor who come for the sake of a holiday, and earning money against winter; the sick poor, who find that no doctor's stuff does them half the good that the smell of the hop-flower does; the poor who are poor because they are drunken, improvident, and thriftless. All these classes go to make up the population who squat upon the rich garden grounds of Kent in September. They have been turbulent and riotous, the evil infecting the good; they have been drunken and unmanageable; and they have occasionally destroyed the flowers they came to preserve; but within the last five years a wonderful change has come over them; and the fact that now the service of only one extra constable is required in each parish, during hopping, speaks most loudly for the quietude of manner and of life which are their characteristics. Even in such a centre as Maidstone, with a population of 30,000 inhabitants, where the hop industry finds the capital of Kent, there are only thirty-two extra police put on duty, yet the population is nearly doubled for the time being. 
Another very interesting question for consideration is the sum of money which is annually distributed amongst the hop-pickers in a single season. This must vary very considerably according to the character of the crop, and the estimate be liable to serious deductions, or may fall far below the real truth, but one method of arriving at a conclusion may readily be tested. Mr. William Nethersole, formerly a large hop-grower in East Kent, when giving evidence before the Select Committee on the Hop Industry, in March, 1890, said " on twenty-six acres of hops last year the picking alone cost $£ 300$." Now in 1889 there were 35,487 acres growing hops in Kent, and at the rate mentioned by Mr. Nethersole the picking would have cost upwards of $£ 400,000$. This would, however, be a very unsafe method of arriving at the average sum distributed amongst the pickers, because the yield is so unequal in the several gardens. The total produce of hops in 1889 , grown in Kent, was 331,656 cwts. ; taking 85 bushels to the cwt., this would amount to $27,190,760$ bushels. The Hopper receives one shilling for every five or six bushels picked. Therefore, if the tally in 1889 was six bushels for a shilling, there must have been $£ 226,589$ paid away; and if the tally was five bushels for a shilling, there was distributed amongst the pickers $£ 271,907$. At a tally of six bushels for a shilling, this would give $30 /-$ a head to 150,000 pickers; but the average earnings of a picker are about $£_{3}$; therefore the pickers in Kent in an ordinary season would not probably exceed 75,000 ; taking men, women, and children together, nearly 80,000 .

When the time for Hop-picking has come, the farmer appoints his Binmen, the number varying according to the extent and number of his gardens. These men are usually labourers who are in his own employ, and in whom confidence can be placed for their fairness towards both owner and Hopper. The 
Binman's duties are to cut the bines about the poles, raise the poles with the aid of his hop-dog (a pole furnished with iron teeth), and lay the poles, with the clustering hops about them, across the bins for the pickers. Then the companies are formed.

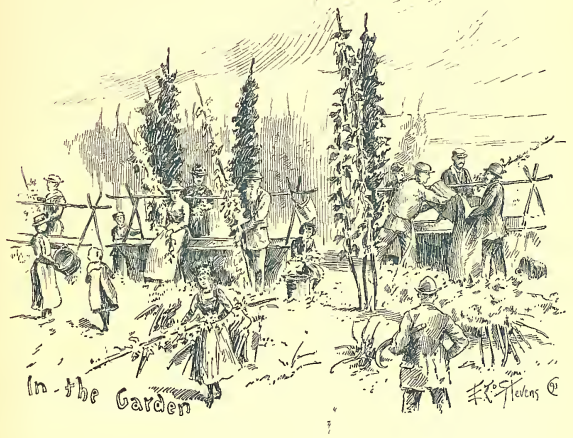

In each company there should be not less than ten pickers; frequently there are more, because a man and his wife with married and unmarried sons and daughters will work together; and the growers much prefer a family arrangement of this kind, 
the work of picking being carried on in a far more satisfactory manner than where the company is made up of elements having no interest in common. To each company there is assigned one bin. This is a square bag of canvas, supported by sticks at the ends where they rise to a point, with poles at the edges (like those of a sedan chair) for the convenience of moving from point to point in the garden. Each bin will hold fifty bushels of hops. Then there are Measurers and Bookers, who have difficult tasks to perform very often amongst the Hoppers, particularly in bad seasons, when the crop falls short of the grower's expectation, and the tally is too high to please the hoppers. Soon after picking has commenced, the Measurer and the Booker make their appearance. The Measurer takes a bushel measure in hand, and fills it by drawing the hops in out of the bin with a sweeping movement of his arms. He must not press the hops in, or the Hoppers cry out against him at once. Then the bushel is emptied into a hop poke, a canvas sack 6 feet high and 2 feet wide, which will hold ten bushels; and three or four times a day a wagon collects the pokes and carts them off to the oast-house. As soon as the Measurer has emptied a bin, the number of bushels is entered at once by the Booker in the book he carries, and also in the book of the head of the company working at the bin. Each night the Booker gives up his book to the Head-picker, or Superintendent of the garden, who transfers the figures into the proper farm book for record and reference.

The huts for the use of the Hoppers generally stand in rows of eight houses; with a cook and wash-house in the middle ; and are divided into eight compartments, each about 12 feet square. One company, numbering ten persons, is assigned to each compartment. The floor is thickly littered with straw for sleeping, but no chairs, forms, or tables are provided. Hanging on an iron 
nail in the wall is an old lantern, in which the Hopper burns a candle. Washing conveniences are found by the Hoppers, and in many instances they bring bedding with them to lay over the straw. There is a separate entrance to each hut. The cook and wash-house is usually in the centre of each row of huts; the front is open to the air; and there are three or four fireplaces in each. The farmer finds the Hoppers faggots for burning;

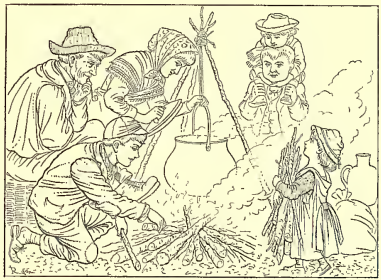

affixes hooks on which to hang the kettles, and six pots can hang at one time over the fires. These huts are built of bricks, roofed with tiles, and are one storey in height. There is little wonder that the washing should be clone in the open air, and the hedges, or the grass, utilised for drying purposes.

On the first day of picking, a horn is sounded in each garden to collect the different companies together, and the Overlooker addressing them, says :- 
"Now these are the Rules in this Garden:

"Pole-Pullers, - Wages to be — per day, or in proportion thereto for the time he may be employed; to be in the hop garden by six o'clock in the morning; to pull poles to — pickers; to look after the pickers, and require them to pick their hops well; and to pick up all hops they may have dropped on the ground near the bins; to use the hop-dog, and not to break any poles through carelessness or negligence; to attend to and assist the Measurer; to assist in moving the bins; to carry off the pokes, and load the same on the wagon whenever required; to assist the other pole-pullers at the last measuring of the day. For every breach of the above regulations the pole-puller shall forfeit $3 \mathrm{~d}$. To take care of the bins, cloths, pokes, and hop-dog committed to his charge, and to deliver up the same in good order at the end of the picking, or on leaving his place; in default thereof pay the cost of replacing what may be missing or unfairly damaged. If discharged for bad conduct, or for not observing these regulations, to forfeit one day's wages.

"Hop-Pickers.--All pickers to pick the hops well to their employer's satisfaction, and to be subject to the regulations herein set forth; and after the tally shall have been set, they are to remain until the picking is all finished; to pick up all hops dropped near their bins; and to have their hops ready for the measurer, so that no delay may arise; to be in the hop-gardens and to remain there at the appointed hours. For every breach of these regulations to forfeit one bushel of hops. The tally to be set during the first week of the picking, if not previously set; but any picker who shall leave before the picking is finished, or who shall be discharged for conduct not in accordance with the foregoing regulations, or for other misconduct, shall be paid off at the rate of one shilling for every twelve bushels.

"General Regulations. - Signal to be given by blowing a horn, or otherwise, when the picking is to be commenced or left off. No hops to be picked during dinner-time; no lucifer matches to be used within the distance of five hills from a bin; no smoking allowed near the buildings or premises; no fire or light to be used after nine o'clock in the evening, except on Saturdays, and no smoking allowed after that hour; no spirituous liquors to be sold or bought in the hop-gardens; no abusive, improper, or immoral language to be made use of; and no quarrelling or fighting to 
take place. For any breach of these general orders, the person offending shall forfeit one shilling. All forfeits to be taken account of by the Measurer at the time, and the amount to be deducted from the sums due to the offenders when paid at the finish of the picking.

" hat Take Notice, that all persons guilty of taking away poles, fruit, or of any illegal act, will be prosecuted."

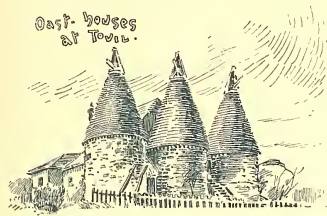

The hours of labour are from 7 a.m. to noon, and from I p.m. to 6 p.m.; on Saturday work ceases at two. A horn is blown by the Overseer in each garden as a signal for beginning or leaving off work.

EFithen

HoP Picking.-BinMan AND others.-OASt Houses.

When picking has begun the scene is always one of great charm, the long avenues of poles loaded with the clustering fruit of brown and gold, through which the sun glints upon the faces and figures of the workers; the little groups about the bins; the children sitting around umbrellas, or dancing about, dressed with wild flowers; the merry laughter and the jocund song go to make up a pleasant scene of rural life.

A wagon goes round the garden three or four times a day, in order to collect the pokes and carry them to the oast houses. These are circular brick buildings, with great movable cowls, and furnished with kilns for drying the hop. They cost from $f 600$ to $f 800$ each; and here the important work of drying the hops is carried on without intermission day and night, until the whole crop is completed. The work of drying is delicate and 
onerous, and a slight inattention would spoil the sale of a pocket. In every oast house there are from three to six kilns, and each kiln will take twenty pokes of hops twice in the twenty-four hours. The hop-dryers, as the labourers here are called, work

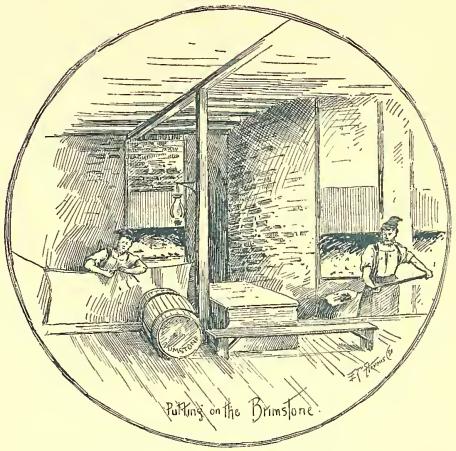

in two shifts - night and day. One man with two helpers will attend to four kilns; and there are from three to six kilns in each oast house. In the centre of the oast house is a fire, and above is the round cowl. A few feet above the fire are some wooden bars, on which is spread a hair cloth; the hops are placed on this cloth to dry; and the kiln-man must pay close attention to 
his work, or the hops will be ruined by improper curing. The process of drying usually occupies from seven to ten hours; and once during that time a spadeful of brimstone is flung over the fire, the fumes of which give colour to the hops. After drying, the hops are placed in the stowage room to cool, and then they are compressed into huge canvas bags, called pockets, each containing $x \mathrm{x} / \mathrm{c} \mathrm{cwt}$. The illustrations show the kilnmen at work in the oast houses.

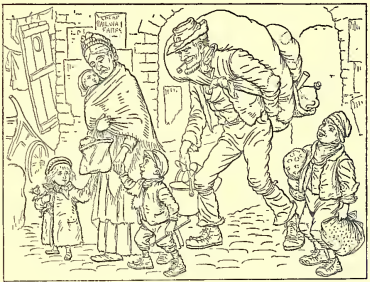

Hop-Pickers Leaving London Slums.

The elite of the Hoppers travel by rail to the hop-gardens; and the trains which convey them usually leave London at midnight on Saturday. Lodgings are given up on that evening; and parties may be seen congregating about the slums of the East preparatory to the tramp to the Bricklayers' Arms Station of the South Eastern Railway. Every group includes children; and these are full of joy at the prospect of the country holiday, seeing 
once again the green fields, the running streams, hearing the real lark in a real sky, and picking and wearing real flowers. They are not concerned about the tattered clothes they have, the howdyish bonnets that the girls wear-those long curtains are to keep the sun off-only to think that the sun shines away down in the hop gardens all day long, and is so dreadfully hot that one can hardly bear it. These things are what they say to one another, with laughing eyes, and they long to be off. Then Mike and Pat have their own confidences and remembrances to exchange one with the other. Mike knows an apple tree "down there" whose branches hang over into the roadway, and by getting on to a wall he can reach the apples, all red and juicy, and altogether unlike the crabby, sour things which father hawks about the streets; and Pat knows a spot by the bridge where he caught an eel last autumn-an eel which has grown in length every week since, and is now as long as his arm and the thickness thereof. They have all got something to carry-bundles, out of which spouts stick or handles protrude, suggestive of kettles and frying-pans. Biddy is full of concern as she numbers her jewels and counts her wraps, and wonders how long "auld Mike" will be before he has drunk the very last drop of something hot and strong against the draughts of the railway carriage on a night journey. Mike has his own gloomy forebodings about the down journey, and gulps his troubles with his gin; but Biddy, more philosophical, has that in a corner of her breast. wrapped up in a rag, which Mrs. Corcorran, "rest her soul," would insist upon lending "over against sudden trouble." That phrase meant Mike, but Biddy will keep a sharp eye on Mike, "hasn't he promised?" and he knows nothing of the two "arf crowns," which Biddy never loses out of her sight. At last, bundles are shouldered, and the march commences, until the 
company is lost in another greater company at the railway station; and after a great deal of unnecessary pushing and shouting the first train is loaded and despatched on that journey, which will end at two or three on the Sunday morning; and the poor creatures will find lusty friends waiting for them, with abundance of hot cocoa or hot coffee, and such slices of bread and butter, of cake, and of bread and jam, as the little ones who have not been hopping before never could even have dreamed.

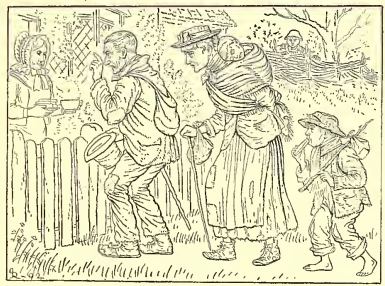

ON THE ROAD.

Many of the old hands who own a barrow or cart, with pony or donkey, drive down to Kent on the Sunday before hopping begins. These belong to the cream of Coster society ; and no four-in-hand on Derby day is tooled with more affectation of style than these equipages, heaped high in the middle with bundles, and carrying the costers seated round the sides, their legs swinging to and fro, while the pony or donkey ambles along apparently in full accord with the merry ones behind him. 
There are other Hoppers who tramp into Kent; these men and women spend the night at the several casual wards of the parishes through which they pass, or they sleep on door-steps, and are furnished with a ration of bread out of parish funds. As many as from 600 to 700 press into the Coxheath Maidstone Union nightly during the season.

When the companies are fairly at work in the gardens many of the youngsters are found to be too small to reach to the top

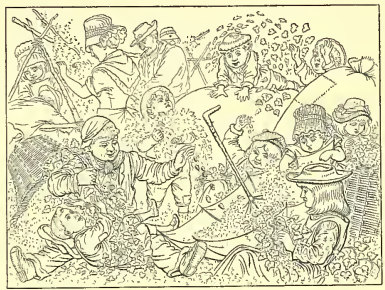

of the bin, and for them the family umbrella is utilised with admirable effect. The children sit around the open umbrella, father or mother flings a hop bine across, and little fingers soon grow expert in plucking the flowers, and do the work more cleanly, and without the intrusion of leaves which often causes a wrangle between the Pickers and the Measurers.

The change wrought in the children by a few days is something wonderful. They are really in the land where the sun 
shines; they can see the trees; can hear the birds; know what a real cow is and imitate the voice; they can strip festoons of honeysuckle and convolvulus from the hedge sides, and deck their hats and bonnets with poppies or the grape-like bunches of blue and gold hop-flower. This is the happy land of which they have learned to sing ; and they are no longer gutter children, but princesses and ladies by native right. Every day at dinnertime they play at being duchesses and queens, and Mary or

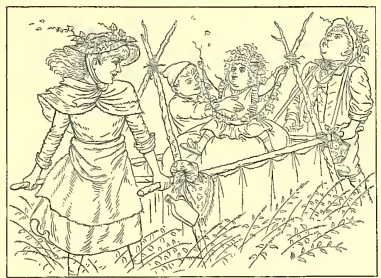

Annie is throned in a bin, covered with flowers and hop-grape, amid the shouts and rejoicing of all, whose homage knows no jealousy, and is rendered without stint or sorrow. Fathers and mothers look on with pride at the natural beauty they have never recognised before in their children, and no one is afraid of a voice suddenly exclaiming "now then, move on there!" or "go indoors!" 
The children, however, have many an awful fright before they get accustomed to the insects common to a hop-garden. A tailor, with his multitude of legs, makes them scream with fright as he creeps towards their hands ; daddy-long-legs, who approaches them with a sort of a "get-out-of-the-way-don't-you-see-I'mcoming" stride, causes some of the youngsters to bolt; while the bee, with his determined "hum thrum," the wasp with his spiteful ways, and the dragon-fly with his green scales and daring dash, cause endless confusion, and loud shouts for Mammy or Dad to come to the rescue.

The children are such capital workers, and exercise such a controlling influence upon the older members of a company, that they are always welcome. A few years ago a young Irish widow made a considerable sensation by attending the hop-pickings with a company of children, who got to be known as "The Widow's Pocket." Kate Hannagan was a daughter of Erin, who migrated to "these parts" during a year when the famine was very bad in the "ould counthry." She and her parents settled at Deptford, where her father got employment as a labourer; and at "hopping" time they worked in a garden with other "strangers." This was the manner of her introduction to an industry which exercises a natural fascination for all who are fond of open-air pursuits. The father and mother made their appearance for two or three hoppings in succession, and then suddenly disappeared, and Kate, as the wife of Michael Hannagan, reappeared amongst the "strangers" in the gardens where she had worked with her father and mother. There was nothing at all remarkable in this; nor in the subsequent death of her husband, though every one regretted this event, and spoke of Kate as being " unlucky," and hinted that if she and her husband had only "took on" the ways of other people, 
and not been so proudish, they might have lived together many years. Which meant that if they had spent all their earnings in mad carousals, and taken part in the faction fights which were of nightly occurrence, the husband would not so readily have succumbed to the mild attack of fever which carried him offwhich was a very curious sort of argument to any mind but that of an Irish stranger engaged in hopping. They were described

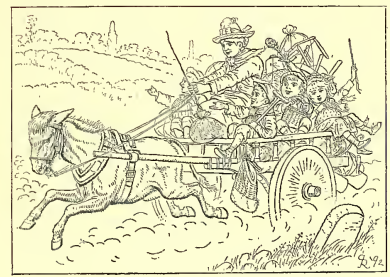

Widow Hannagan's "Big Pocket."

as "lonely" people during their brief married life, because they preferred each other's company to the noisy clangour of half a dozen neighbours who cared nothing about them, but everything about what could be got out of them. But they were never so lonely as to want a third person to show them their way about the dark lanes at night; and many a party half crazy with fright, losing their way home, had crossed themselves with devout thankfulness as they heard the voices of Michael and Kate 
blending in an Irish duet, and knew that they could not then be far away from the Hoppers' settlement. But Michael died, and Kate and the world were alone. Then it was that she formed a "Pocket," for the joy of herself and all that were in it; year by year attended hopping in all the gardens; and became widely known for the great love she showed to her Pocket; and though childless became a happy mother; never lacked for company of the brightest and the sweetest; and by her example gave rise to the formation of "Pockets" which flourished for years. This "Pocket" never was seen in any warehouse in the borough; but it was so called in imitation of the great "pocket" of hops, which was the product of the garden and the labour of the strangers. Kate Hannagan's Pocket consisted of ten or a dozen children, whose ages ranged from eight to ten, forming a "company." The children were of both sexes, and were representative of eight or nine families, whose parents were unable to take to hopping as a whole, and were glad to let the young Widow Hannagan take them for an outing in the hopping time. They were not selected because they were so to say "the flower of the family," but very frequently were little ones who could only walk with the aid of a crutch; whose wan faces spoke of a languishing for lack of summer sun and autumn air. Mothers who were confident that their Pat - as strong as a lion, would be sure of being chosen, were often sorely puzzled by Widow Hannagan preferring little Mike who could only creep to the door on very sunny days, and whose legs appeared utterly unable to sustain the withered trurik above them. When the "Pocket" was finally selected, they were collected in a donkey-cart; pots and pans, and rough bedding stuff in the centre, with the handle of a gigantic umbrella sticking up, and looking with the head and face of an ogre upon 
all about; round the sides the eight or ten youngsters; the Widow Hannagan in the front, reins in hand, and at the word "go" nobody ever knew "Poke" the donkey to do anything else than go at his level best. The Widow and her Pocket always got employment in the season. Farmers never had any trouble with the family; they never gave themselves airs with the police, or quarrelled with the Measurer; or found fault with the tally being too high; or used bad language. They were always first of all the strangers to turn up in the garden; went direct to their hop house after work; and were amongst the earliest customers for the slices of bread and jam, which is the dream of a young hopper eleven months out of every twelve. The Widow did wonders with the "Pocket"; those too small to stand round the bin, sat around the ogreish umbrella opened wide upon the ground, and plucked the grolden fruit and cast it in ; and the Giant whom Jack killed--for it was really his head-was almost caught smiling on occasions when the wan faces became warm red and then deepened into a decided brown, and worn spirits brightened and young laughter rippled over rosy lips.

The Widow's hop book always totalled up well at the end of the picking ; and every little one not only went home entiched in health and with strength invigorated, but with warm clothing for the winter.

There were always a good many strangers to look over the garden when picking was going on; but why they should all prefer the "Widow Hannagan's Pocket" to the bins where the maidens were always waiting to toss or be tossed amongst the hops, was no small amount of mystery. But there was one merry-mannered, black-faced Irish giant, named "Patrick the Great," and as soon as his voice was heard singing out "Lolly, Lolly, or Lemonalley," there was just a shade more colour in 
the Widow's face, and he had time to notice it before he scattered a handful of sweets amongst the little umbrella pickers. Yet several years elapsed, and they met time after time "hopping," before she finally consented to give him just one long trial, and they emigrated to Canada, where they are now doing well farming in Manitoba.

The example which the Widow Hannagan set has been one which is now very commonly followed in all districts of Kent. If there is a poor bed-ridden cottager, a bin is taken in her name, and all who know her will give a day or two picking in the season; or if some local charity is in want of funds a bin is taken, and picking is carried on in the holy name of charity.

Sunday is the great visiting day amongst the Hoppers. Then come friends from London to entertain or be entertained. The local beerhouse keeper and publican makes his appearance, and stands treat to all his London customers, or scatters bronze money amongst the crowds in the market places. Poor relatives come down in borrowed carts, and for their entertainment, many a company gets into trouble because of their absolute ignorance of the rules of "mine and thine." One company, anxious to give a good dinner, borrowed some chickens from a farmer's henroost, and were tracked early on Sunday morning by the farmer's son by the feathers which were dropped. Summoning to his aid the parish constable, there was no difficulty at all experienced in discovering the very pot which contained the lost chickens. There they were found, the bodies simply plucked of feathers, boiling with potatoes, and cabbage, and mutton, and dire lamentations followed the discovery as big Pat, the father, was hurried off to a different sort of meal in the lock-up.

The Hoppers show a great aversion to the country dogs and to the darkness at night. A little dog in a cottage garden, or at 
a farm, will secure the place from trespass; and the aversion seems to be unconquerable on both sides. No dog will make friends with a Hopper; and no Hopper will go where a dog is known to be running loose. In the evenings also the strangers show

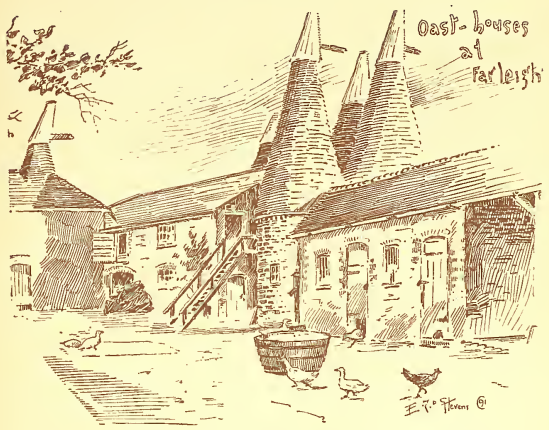

a childish dread of the dark. One man or woman is never met alone ; they go in twos, threes, or larger numbers; they straggle along the roads as they walk, often lose one another, and sing or shout to keep up their spirits. The cottager is constantly roused from sleep at night by the noisy singing of concert hall songs, such as "Comrades"; "Hi Tiddley $\mathrm{Hi} \mathrm{Ti";} \mathrm{or} \mathrm{the}$ strains of "Annie Rooney." 
The Hoppers live upon fish, tinned meat, and German sausages during the week; and upon Sunday have a joint bedded upon potatoes roasted at the local oven. About the hour for going to church the Hoppers may be met carrying their baking tins to the oven; and scarcely less than from seventy to one hundred tins are received at the baker's on the Sunday morning. Fetching the joint home is a matter of much ceremony ; and no single man or woman is entrusted with the sole care of the tin, there is always an escort to relieve the carrier, and generally to ensure the safety of the dinner. During sermon time, the women finish up their clothes washing, wringing, and drying - the grass and the hedges are littered with the garments of the poor people; and the youths and men either bathe, with a great deal of unnecessary shouting, or try their hand at fishing. As there are no tables in the huts, the tin of food is placed on the ground, and the family squat around. The mother or father cuts the joint with any sort of cutting tool which is handy, frequently a pocket knife, and the hungry workers help themselves out of the dish with anything capable of spitting a potato, or holding it while being devoured. The utility of fingers comes into admirable display on these occasions. After dinner the men smoke, or visit ; the women gossip; and the children play. As soon as the public-houses are open, there is a general migration in their direction, and drinking and singing proceed until closing time. But the beershops are now closely run by the coffee-houses, where wholesome and well-cooked victuals are supplied; where the strangers always receive a hearty welcome; and where ladies and gentlemen without any air of superiority mingle with the people, advise with them, and encourage them to make a stand against the terrible temptations which dog their every step. During the week nights the girls are taught to read and 
write ; to mend their own clothes and to cook; and thus they learn to become self-reliant and hopeful for the future.

The costers of the East-end follow their customers in great numbers; and set up their stalls in the village market places, selling tinned food, joints, or knuckles of ham at low prices. They remain throughout the season; and drive a rattling trade when the harvest is a good one. Fresh supplies come down by train ; and the Hoppers, who are naturally suspicious, prefer trading with these men, to dealing exclusively with little shopkeepers.

The same costermongers come down to the same villages year after year. "Ned" is always to be found at the corner by the pub. with tinned meat; and close beside him "Tommy" with stores of fish-bloaters, kippers, herrings ; and "Snooks" deals in bacon and cheese. Inspectors, in the service of the local authority, are constantly going round, and bad food is invariably seized. The local shopkeeper has to compete with these "stranger merchants"; and keeps his own position well. He has this advantage over the costers; he lays in stocks of articles which the Hopper requires, and sells at low prices. Empty meat tins in which to boil potatoes are given to customers; margarine tubs for washing are sold for $11 / 2 \mathrm{~d}$. or $2 \mathrm{~d}$. each; while tin kettles which hold two gallons are retailed at from 4d. to rid.

As to the earnings of a Hopper, an average is hard to ascertain, on account of the variation of the seasons and the number who pick together; but it probably averages $\mathscr{E}_{\mathrm{I}}$ a week.

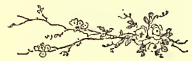


Following is a copy of the book of a "Home picker," an old woman well known in Yalding, picking at a half-bin, divided for her use.

BINMAN. PICKER.

\begin{tabular}{|c|c|c|c|c|c|c|c|c|}
\hline \multirow[t]{2}{*}{ Date. } & \multirow[b]{2}{*}{ I } & \multicolumn{3}{|c|}{ Measuringss. } & \multirow[b]{2}{*}{5} & \multirow[t]{2}{*}{ Total. } & \multirow[t]{2}{*}{ Tally. } & \multirow{2}{*}{$\begin{array}{l}\text { Cash Paid. } \\
\text { [None.] }\end{array}$} \\
\hline & & 2 & 3 & 4 & & & & \\
\hline $\begin{array}{c}\text { r8gx. } \\
\text { Sept. } 8 \ldots\end{array}$ & 5 & 5 & . & & & Io & 6 Bushels for $1 /-$ & \\
\hline , $9 \ldots$ & 3 & 7 & 3 & .. & & 13 & & \\
\hline, $10 \ldots$ & 8 & 6 & 3 & ... & 1. & $\mathrm{I}_{7}$ & & \\
\hline,$\quad$ II $\ldots$ & 5 & 5 & 3 & ... & & $\mathrm{r}_{3}$ & & \\
\hline, $12 \ldots$ & 6 & 4 & I & .. & $\ldots$ & II & & \\
\hline " $14 \ldots$ & 7 & 5 & ... & ...... & & 12 & & \\
\hline, $15 \ldots$ & 6 & 4 & 7 & ... & 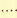 & ${ }^{17} 7$ & & \\
\hline , $16 \ldots$ & 9 & 6 & 5 & ..... & & 20 & & \\
\hline, $17 \ldots$ & 5 & 5 & 2 & 6 & & 18 & 4 & \\
\hline,,$\quad 18 \ldots$ & II & 6 & 5 & & & 22 & & \\
\hline ," $19 \ldots$ & 7 & 8 & $\cdots$ & & & $I_{5}$ & & \\
\hline$" 2 I \ldots$ & 9 & 6 & 4 & & & 19 & 5 Bushels for $1 /-$ & I68 Bushels \\
\hline, $22 \ldots$ & 7 & 7 & ...... & ... & & 14 & & at 6 for $1 /$ - \\
\hline, $23 \ldots$ & 9 & 8 & 3 & $\ldots$ & & 20 & & \\
\hline, $24 \ldots$ & 6 & 7 & 2 & $\ldots$ & . & ${ }^{15}$ & & \\
\hline$\Rightarrow \quad 25 \ldots$ & 6 & 4 & 4 & ... & & I4 & & \\
\hline, $26 \ldots$ & Io & 9 & $\because$ & & & 19 & & \\
\hline , $28 \ldots$ & 8 & 5 & $\dot{5}$ & ... & & 18 & & \\
\hline , $29 \ldots$ & $\dot{9}$ & 5 & 5 & .. & & I9 & & \\
\hline$\Rightarrow 30 \ldots$ & 5 & 6 & 3 & & & I4 & & \\
\hline Oct. I ... & 2 & 2 & & & & 4 & & \\
\hline & & & & & & & & $\begin{array}{l}\text { I } 56 \text { Bushels } \\
\text { at } 5 \text { for } x /-\end{array}$ \\
\hline
\end{tabular}

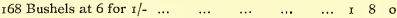

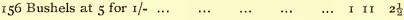

Earned in three weeks

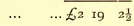


Here is another fair copy of the pickers' account book, and represents the earnings of an old one-legged pensioner, with his wife, son, and daughter, picking at one bin.

BINMAN.

Picker.

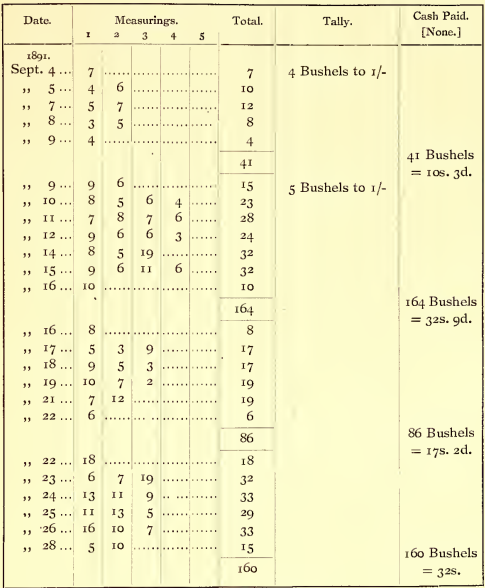

Total earnings in four weeks... 
That $£_{3}$ per head is a fair average to take, is furnished by another and most interesting example. Mention has already been made of the farmers' preference for a family. This is the case of a rather large family to whom were allotted four bins. At No. I was the mother and three children; No. 2, a son, his wife, and two children; No. 3 , grown-up son and daughter; No. 4, daughter-in-law, with her brother and sister. The father acted as Binman in another portion of the garden, and received $£ 3$ 3s. od. No money was drawn by any member of the family during the three weeks they were employed; they were all teetotallers and drank no intoxicating liquor, and at the finish of the picking they drew $£ 35$ 7s., which was transmitted to their homes by the Post Office Savings Bank. The money was made up as follows :

Eight adult pickers at $3 /$ per day for 21 days

Five children earned

$$
\begin{array}{rrrr} 
& \& & \text { s. } & \text { d. } \\
\ldots & 25 & 4 & 0 \\
\ldots & 7 & 0 & 0 \\
\ldots & 3 & 3 & 0 \\
\hline & 635 & 7 & 0
\end{array}
$$$$
\text { The father's earnings as Binman }
$$

The question naturally occurs, what becomes of all this money which is earned season after season? and the reply must be that, notwithstanding a very great deal of good work done by certain societies, and by local charitable organisations, a vast proportion is spent in intoxicating liquors. For nearly a quarter of a century one gentleman beyond all others has identified himself as the champion of the poor Hopper, and by his untiring zeal and Christian earnestness, hạs won for these people a legal recognition and a civil treatment to which for many years they were strangers. This is the Rev. J. G. Stratton, Rector of Ditton, Kent, the Secretary of "The Society for the Conveyance and Improved Lodging of Hop-Pickers ;" and of "The Church of England Missionary Association for Hop-Pickers and others." 
The construction of hop-huts, and the sanitary accommodation provided; the inspection of the food and water supply ; and the improved arrangements for the transportation of the people to and fro, are due entirely to him; and every season a large number of missionaries are sent through his instrumentality to labour amongst the people while they remain in the district. Local efforts are also made in many districts by large-hearted Christian people-chief amongst them being ladies, who, by direct contact with the Hoppers, seek to raise them morally as well as physically in the scale of social life. The following letter from one actively engaged in this work at Yalding, is written in enthusiastic terms, and shows the spirit which actuates those engaged in it :--

"It is now four years since the tea and coffee-room for the Hoppers was first opened at Yalding, and the success it has achieved has been far beyond the most sanguine expectations. Begun under great difficulties, and carried out against a good deal of opposition, it has proved itself both a boon and a necessity, and is fully appreciated by our annual visitors. The object. of this work was not only to show our sympathy for them by providing good food and drink, but, by having a place where non-intoxicating refreshments could be obtained, to keep them, if possible, from the contaminating influence of the public-house, in hopes that the good work which others had been doing elsewhere, might be carried on here while they are with us, and that they may be encouraged to lead a sober and better life.

"There is not the slightest doubt that so complete a success is entirely due to the fact of their being supplied with things of the best quality, in a thoroughly clean manner; this combined with cheapness has proved irresistible, and we now have the satisfaction of knowing that many who would otherwise have spent 
the whole of their money in public-houses, have come to us and had a hearty meal for a very trifle, and then returned to their homes (for the time being) thoroughly satisfied and comfortable in themselves. Many a time has it been said to us when we have given them change out of silver, 'Ah sir, or marm, if I had gone in next door (a public-house) I should have left all my money there, but now I can take it home'; and it is a significant fact, that during the four years it has been open we have not received one act of incivility from them ; that, I think, is a proof that they are human beings and appreciate kindness.

"Some idea of the amount of work it involves may be gathered when I say that nothing is charged for above one halfpenny. Tea or coffee, halfpenny per half pint; large slice bread and butter, bread and jam, or cake, one halfpenny each; only enough profit is made out of it to cover expenses, and, as nearly the whole of the workers are volunteers, the Hoppers get quite full value for their money.

"The work first begins on a Saturday night: we are then at the railway station preparing for their arrival from London. Each person has his allotted place and work. By one o'clock Sunday morning, everything is in readiness, loaves and cakes all cut up, gallons of boiling water, and we only await the signal from the next station that the first train is coming, and then in goes the tea and coffee. A very few minutes after the train arrives, and then the work begins in earnest; hardly before one train load is supplied, another comes in ; sometimes two at once, hundreds alighting from each. The din is deafening. Mothers yelling for their children lost in the darkness, children crying for their mothers, and every one else seeming to be trying to yell their loudest, as if to frighten the darkness, and the majority of them shivering with the cold. But as soon as the coffee-stall is seen a 
rush is made for it and the din increases ; everybody wants to be served first, dozens at a time asking for tea or coffee, and there is a constant struggle among themselves for it; and to see the boiling liquid go down their throats without any apparent discomfort, makes us think that either their temperature is very low, or that they are used to something both stronger and hotter. But at last all are satisfied, and to see the contented faces and to hear the God's blessings, amply repays us for the loss of a night's sleep. Soon as the day breaks they shoulder their bundles, and march away to their different farms, singing.

"The coffee-room, which is in the centre of the village, is open every evening (except Sunday), from five o'clock till nearly nine. The building not being very large, having only two small rooms on the ground floor, wooden benches are fixed up outside, and it is indeed a pleasant sight to see them, while it is daylight, sitting there enjoying a good tea, while others are lying about on the grass, and all appearing thoroughly happy. Amongst them are many young single fellows, who would not trouble to make tea themselves, but would have resorted to the publichouse had it not been for this. To these it is a great blessing, and they seem to be deeply thankful, for some have said it is the one thing they look forward to, being the only meal they have during the day, a sign evidently that the things are good and that they enjoy them.

"The work at the coffee-room is more steady than at the station, though at times there are rushes, but even if a little delay does occur perfect good humour prevails. Accidents, though upsetting the equilibrium, do not seem to upset the general good feeling, for one evening five very stout ladies were sitting upon one of the benches, evidently enjoying the good things, which had a different effect upon them from that supplied 
by the publican, for while his would have made them light headed, ours were nourishing the body so rapidly that the bench was unable to bear the accumulating weight, and suddenly collapsed, to the great amusement of all, including the fallen ones themselves.

"The effort to make everything appear inviting is apparently not without success, and it is often a matter of surprise to see how much one person can stow away. From the remark of a man one evening, it is evident that they feast the eyes as well as the body, and that the latter becomes satisfied first. He had undoubtedly been doing justice to his capacity as well as the food, but at last he was beaten, he was unable to finish the last piece ; looking up to the lady who had served him, he said with a grin, 'my eyes were bigger than my belly, mum.'

"And now, putting aside all other questions, and coming to the point. Is the work doing good? I think there can be but one opinion, and that is, that of the many good works which have been done for the benefit of the Hoppers this is one; if not the best. We come to this conclusion from four years' experience. From the Hoppers themselves who have come year after year we have had proof; from the inhabitants of Yalding, and even from the police; for it is an acknowledged fact that last year there was less rioting and drunkenness here than ever was known before, in fact it was almost $n i l$; and the coffee-room is believed to be the chief agent in attaining that happy state of things. Not that we wish to sing our own praises, but in hopes that it will stimulate others to do the same, though at the same time I do not think any praise can be too great to that noble band of ladies who, in giving up both time and pleasure, have practised that greatest of all Christian virtues - self-denial, and carried on a work which is not at all times pleasant, but which 
they do in hopes that some fellow creature may be encouraged to lead a better life. This is indeed Christian work, and worthy of great praise, and which will have gained its reward when Christ, for whom they have worked, says, 'Well done, good and faithful servant.",

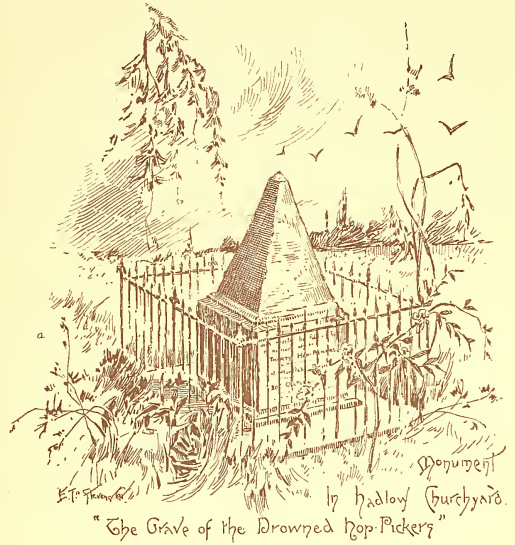


During the hopping season of 1847 , a dreadful calamity happened which struck the whole country with horror, and which has given the title to the illustration on this page. This is a view of Hartlake Bridge, an old fashioned structure of wood, common enough in the county. There had been a flood-a most unusual occurrence at the season of the year-and some low-lying gardens, where gipsy pickers were at work, became flooded so as to hinder picking. The farmer having other gardens high and dry, resolved to transfer the Hoppers from one ground to the other. As the river Medway separated the two gardens, and the approaches to the bridge were flooded, the farmer sent a wagon drawn by two horses tandem fashion, to bring off the people. The wagon was duly loaded-there being between thirty and forty in it-and started to cross the bridge. On the fore horse rode a labourer. When they came to the river they found that the flood had risen suddenly, and the water was rushing over the level of the bridge. Not thinking of any danger, the wagon drove on to the bridge, and when half-way across, the horse in the shafts swerved a foot or two, causing the vehicle to strike the centre post of the structure. In an instant the post snapped, and the water carried the wagon over the side, capsizing as it fell. The poor gipsies had little chance of saving their lives, and thirty men, women, and young girls met a watery grave. The shafts broke as the wagon fell into the water, and the horses and driver escaped; but very few of those who were in the wagon were saved. Men who were well-known swimmers perished, along with women and children; one or two were reported to have been washed into trees by the side of the river, and were rescued next day. In one case only a boy survived, while father, mother, sisters and brothers were drowned. Many days elapsed before the 


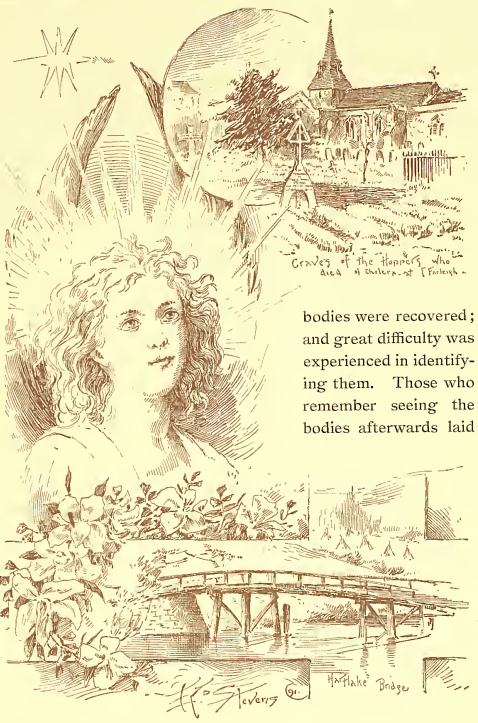


out in barns, still speak of the great beauty of the dead gipsy girls. As soon as the disaster became known, all the gipsy tribes in the country flocked to the quiet Kent village where their dead friends lay, and the mourning was accompanied with the most heartrending demonstrations of grief. The dead gipsies were buried in the churchyard of Hadlow, where, upon a square pillar, there stands a small pyramid, erected to the memory of the unfortunate people. On one side are the following words:- "This monument was erected by Public Subscription in memory of the Thirty Hop-Pickers who were drowned at Hartlake Bridge in a Flood of the river Medway, on the eth of October, $18_{53}$, and whose bodies were buried in this churchyard.

$$
\text { "In the midst of life we are in death." }
$$

On the other sides are the following names:-- "Samuel Leatherland aged 59, Charlotte Leatherland 56 , Comfort Leatherland 24, Selina Leatherland 22, Alice Leatherland 18, John Herne 28, Lunia Herne 26, Centine Herne 4, Herne 2; all one family. - Sarah Tayler aged 55, Thomas Tayler $3^{8}$, Thomas Tayler 4, William Elsley 22, Selina Elsley 25, James Manser I8, Richard Read 30, Ann Howard 49, Selina Maria Knight 6. - Norah Donovan aged 3I, Catharine Roach 2I, Bridget Flinn 2o, Ellen Collins 40, Mary Quinn 22, Jeremiah Murphy 50, Ellen Dwine 19, Margaret Mahoney 18, Catharine Preswell 24, Catharine Clare 28, Catharine Donhohue 42, Margaret King 20 ; all natives of Ireland."

Living amid such surroundings as were common in former years, and treated more like beasts than human creatures, there was little wonder, when disease broke out, that the Hoppers died off rapidly. In September, I849, cholera broke out amongst them in East Farleigh. The weather was hot and 
wet, and the disease raged for nine days, during which, fortythree poor strangers died.- "They dropped," said a man who remembered the occurrence, "like rotten sheep." The Vicar of East Farleigh at the time was the Rev. W. Wilberforce, son of the statesman, and he took immediate steps to check the outbreak ; in his efforts he was ably seconded by the Roman Catholic priest. Government assistance was applied for, and medical men, with all the necessary means for checking the outbreak, were despatched. The poor Hoppers were working for the late Mr. Ellis, a large hop-grower. Tents were sent down for the isolation of those attacked; and a large reserve of tents stacked in the belfry of the church. The disease was appalling in its severity. A man, his wife, and three children died on a Sunday morning, and were buried next day. There are two old women still living at East Farleigh who took part in the nursing of the patients: their names are Granny Cox (Mrs. Jane Cox), and Old Fan (Mrs. Francis Bromley). Mr. Miller, carpenter of West Farleigh, made the cross of oak (shown in the illustration) which now marks the place where the victims were interred. The cross stands 4 feet 6 inches in height, and has upon it these words: "In Memory of Forty-three Strangers, who died of Cholera, September, I849. R.I.P." The circumstance has never been forgotten by the Hoppers, and every season, relatives of the deceased pay a visit to the churchyard where the dead lie. In consequence of this outbreak every public-house in the district now supplies cholera mixture free to all applicants during hop-picking.

One Saturday night, perhaps the first in October, the typical family will return to their old diggings in the slums of the East. Mike flings down his bundle, much the worse for wear, and is off, with one shilling Biddy has given him, to drink "the 
home-coming," and, after things are tidied a bit, she creeps off to Mrs. Corcorran, two halfcrowns and a shilling securely hidden in her dress. After the usual greetings the money is returned, with the interest, and then Biddy opens the bag in her hand, "An' Mrs. Corcorran," she says, "I've brought ye a taste of apples, real ones, growed on a tree, not like those in Ameriky where they grow 'em in barrels. Here," taking one out, "is a Blendem, my dear, which is the curiosest blend I've ever tasted, and never a bit like the cratur sweetened or unsweetened; and this," taking up another, "is a Rustic ; all the country people is called Rustics, and this is named after 'em, brown in colour, like their corduroys, and blessed sweet and nice they are. No, my dear, don't thank me, and I'm ever so much obliged to ye for your kindness."

Then Biddy returns home again, and is fast asleep with the children before Michael rolls in, stupidly drunk; and throughout the winter months there is a daily struggle, and fierce encounters of tongues, because Biddy has so well concealed the little store made by hopping, that Michael cannot find it, and is obliged to do "odd jobs" to keep himself in victuals and drink. Not many, however, are as shrewd as Biddy. The hopping money goes to the beershop all too soon; and the family have to suffer untold hardships through the winter months because of their own improvidence.

That the Hop industry should languish, and fears be entertained of it disappearing altogether, formed sufficient justification for the appointment of the Parliamentary Committee in 1890 to consider all the questions connected with the cultivation of the Hop. Nowhere in the world can such Hops be grown as in the county of Kent; and when the social bearings of the industry are considered - the grand health-holiday which the poor of the 
East end of London enjoy; the money which they earn to help them through the winter; and the happy Christian influences brought to bear upon the Hoppers-the loss caused by the disappearance of the plant from Kentish gardens (which we hope will never happen) would be immeasurable.

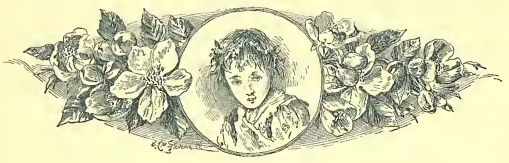




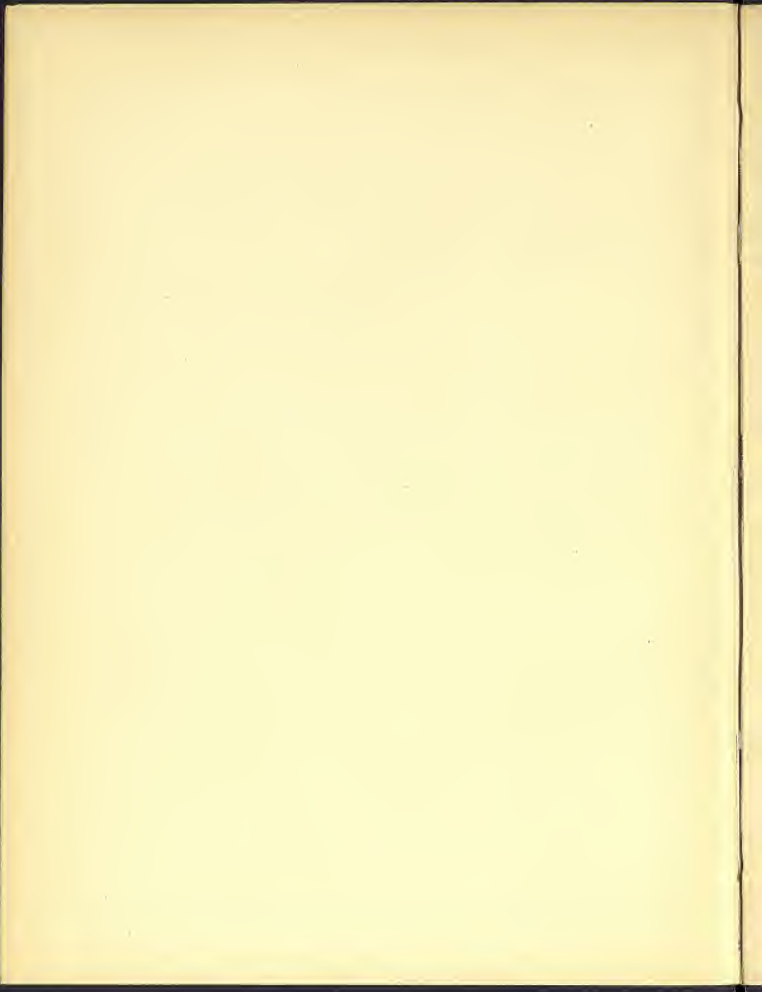




\section{De JMonffort Press Book Iist.}

"St. Paul's Cross: The Most Famous Spot in LoNDON," by John B. Marsh (London: Raithby, Lawrence \& Co., Ltd., I Imperial Buildings, E.C. $3 / 6$ ) though not pretending to be exhaustive, gives all the notable incidents recorded in the annals, diaries, histories, and state papers (domestic series) mentioned as having taken place at this famous old-time preaching place, the arena where great national questions were in olden days usually ventilated and declaimed upon by the ablest preachers, frequently in the presence of the reigning sovereign

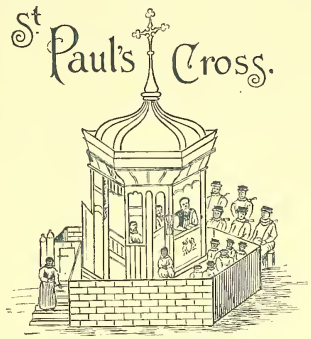

and his or her ministers, or of the Lord Mayor and corporation. Mr. Marsh's work has aroused considerable interest in respect of this historical battle-ground between Popery and Protestantism, and a suggestion has been made that the old cross, the foundations of which are still visible, should be indicated by some suitable memorial. The book is a small 4 to, admirably printed in old style (modernised) type, in red line borders with wide uncut margins, embellished with three illustrations, tastefully bound in black and gold, top edge gilt, and is altogether a model of modern bookmaking.

LONDON : I IMPERIAL BUILDINGS, LUDGATE CIRCUS, E.C. 


\section{De JMonffort Press Book Iisf.}

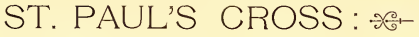

THE MOST FAMOUS SPOT IN LONDON.

\section{PRESS OPINIONS.}

St. Paut's Cross: The Most Famous Spot in London. By John B. Marsh. (Raithby, Lawrence \& Co., I Imperial Buildings, Ludgate Circus, E.C.)- "Preaching crosses" were at one time common in England. They were usually set up in the highway or places of public resort, at which the friars and others were wont to preach. Of these preaching crosses St. Paul's was undoubtedly the most remarkable, and Mr. Marsh has rendered a Yaluable service, not to antiquarians only, but to Londoners generally, by collecting into this very handsomely got up volume all the incidents recorded in the annals, diaries, histories, and state papers (domestic series), mentioned as having taken place at this famous spot. One cannot think of this remarkable preaching place without recalling the name of Bishop Latimer, who often addressed the poople from that spot, and whose wit and homely illustrations as he attacked and satirised the vices of the times, and particularly the ecclesiastics of his day, called forth shouts of applause and the cry: "Have at them, Father Latimcr." There also Richard Hooker, the greatest name in English theological literature, was appointed to preach shortly after his ordination in $15^{\mathrm{B}} \mathrm{I}$. Mr. Marsh deserves hearty thanks for the pains he has bestowed upon the production of this most interesting volume, which should be found in the home of every London citizen, - Christian Age.

ST, PauL's Cross. By John B. Marsh. (Raithby, Lawrence \& Co.) It is a curious sign of the indifference with which famous spots are sometimes trented in England that nothing has been done to denote the site of St. Paul's Cross. Four years ago, when the ground belonging to the great cathedral was laid out as an ornamental garden for public use, the foundation of the ancient pulpit, after being hidden for more than two centuries, uncxpectedly came to light. Yet, although a guestion which had previously excited a little discussion among antiquaries was thus set at rest, we look in vain for a tablet or obelisk drawing attention to the interesting nature of the discovery. Apart from $\mathrm{n}$ well-informed few, the many thousand persons who daily pass the place are never reminded that it is rich in associations with conspicuous figures and events in English history, - The Academy.

THERE are nearly two hundred references here to events, the more important of which shaped the destiny of England for centuries. There was fought out in wordy warfare the contest between Roman Catholicism and the New Religion, as Protestantism was first crulled. Cardinal Wolsey was frequently present at sermons preached here; and a good many books published by Luther, Coverdale, Wycliffe, and others, were here burnt at sermon time.Great Thoughts.

MR. MARsH has put together in a prettily printed little volume all the notices he could find in state papers and diaries of the sermons preached at "Paul's Cross," and other incidents connected with the place, from the reign of Richard I. to A.D. I643, when the cross was taken down by order of the Long Parliament, - Guardian.

Mr. Marsh has industriously laid daries, annals, state papers, whatever he could find bearing even remotely on his subject under contribution. From Irgr, when William Fitz Osbert delivered an oration at the cross, down to $x_{4} 3$, when the Long. Parliament ordered the cross to be taken down, he has noted all the sermons, processions, bible-burnings, proclamations, public abjurations, excommunications, recantations, \&c., of which St. Paul's Cross was the scene,-Birmingham Post.

To the student of history the book will be of great interest, and it may serve to excite a wholesome curiosity in the minds of others as to the general condition of things at the time of some of the more curious incidents recorded. The get-up of the volume reflects grent credit upon the publishers. Paper, type, and illustrations are all of the best, and the carmine borders give an air of distinction to the pages. - Methodist Recorder.

THB publishers have produced a work highly creditable to their laste; the type is new; each page is printed within a frume of great beanty, and the three illustrations are admirable. -City Press.

LONDON: I IMPERIAL BUILDINGS, LUDGATE CIRCUS, E.C. 


\section{De JMonfforl Press Book Irisf.}

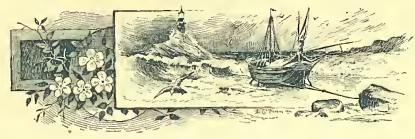

CROWN SVO., CLOTH, BEVELLED BOARDS, ILLUMINATED SIDE, a/6.

\section{AMIDST}

\section{NATURE'S REALMS,}

Or Essays-Zoological, Botanical, and Geological, BY EDWARD ALFRED MARTIN, Author of "Glimpses into Nature's Secrets; or Strolls on Beacle and Dowon."

PART I.-LIFE IN THE LIVING PRESENT. PART II,-ANNALS OF A FAR-AWAY PAST.

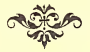

"Amidst Nature's Realms," by the author of "Glimpses into Nature's Secrets," is a series of essays-zoological, botanical, and geological, in two parts : "Life in the Living Present" ; "Annals of a far-away Past." The work, illustrated from photos and drawings by the author, is just issued from the De Montfort Press (1 Imperial-buildings, E.C.) price $2 / 6$.

LONDON : I IMPERIAL BUILDINGS, LUDGATE CIRCUS, E.C. 


\section{De JMonfforf $\mathcal{~ P r e s s ~ B o o k ~ I s i s t . ~}$}

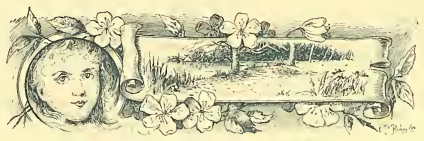

SECOND AND CHEAPER ILLUSTRATED EDITION, PRICE 2/6.

Cloth, Bevelled Boards, Illuminated Side.
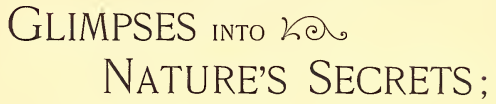

Or Strolls on Beach and Down.

$$
\text { BY EDWARD ALFRED MARTIN, }
$$

Illustrated from Drawings by the Author and others.

\section{PART I.-BY SHORE AND SHALLOW. \\ PART II.-ROCK-WRITTEN STORIES.}

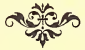

A NEW and cheaper illustrated edition of Mr. E. A. Martin's popular work, "Glimpses into Nature's Secrets," has been issued from the De Montfort Press (I Imperial Buildings, E.C.) The text has been revised throughout and numerous illustrations and diagrams, from sketches by the author and others, help to make the second edition even more acceptable than the first, now out of print.-Literary World.

LONDON : I IMPERIAL BUILDINGS, LUDGATE CIRCUS, E.C. 


\section{De Monffort Jress Book Iist.}

\section{THE NORTH MIDLAND SCHOOL COOKERY BOOK,}

Edited by MRS. BUCK,

Hon. Sec. North Midland (Leicestershire) School of Cookery.

Fifteenth thousand, price Sixpence.

A wonderful sixpennyworth.-Evening News.

A very useful book, by one who evidently understands her subject. - The Vegetarian.

The recipes given - all of which have been the subject of demonstration lessons-are for plais, simple dishes, such as the poor children attending the school would be called on to cook in their cottage homes. As the price of the manual is only sixpence, it is well within the reach of a working-man's wife, and its purchase would save nany a sixpence in the long run, by teaching economy and the art of nourishing cookery at small expense.-Bazaar.

\section{COUNTY COUNCIL COOKERY,}

By MRS. BUCK, Hon, Sec. North Midland School of Cookery.

Compiled to assist Lecturers under the Technical Education Act, and for the use of Students.

Serviceably bound in stout boards. $8 \mathrm{vo}$, price Fourpence.

A capital little manual, calculated to be of great use in helping the popular efforts to disseninate a knowledge of practical cookery. - Carlisle Patriot.

Cookery is now very properly made a subject of instruction in elementary schools, and these little manuals are intended to be used as class books, but they are equally servicable as guides to plain cookery in small households. - Yorkshore Herald.

Specially intended for the use of cookery classes conducted under the Technical Education Act. It is an eminently practical production, and if the wives and daughters of working-men would pay attention to its clear and simple instructions, the averafe level of comfort of the working-man's home could be materially raised.-Illustrated Weekly Telegraph.

\section{SIMPLE RECIPES FOR SICKROOM COOKERY,}

\section{Revised and Enlarged. By MRS. BUCK.}

Second Edition, price Twopence.

A commendable little book. - Evening News.

Treated in a plain homely manner, easily understood.-Loneghorough Herald.

The instructions as to invalid cookery and the recipes it contains are invaluable for homenursing: for the directions are so plainly given that even those quite unskilled in the art of cooking can readily follow them. It is not everyone who knows how to make beef tea, mutton broth, veal tea, linseed tea, barley water, and such invalid drinks; neither are meat and strengthening jellies, savoury custards, nourishing puddings, made without some knowledge. -Basar, Exchange and Mart.

\section{ex THE COMMERCIAL READER, א囚。}

\section{Edited by A. ARTHUR READE.}

Contains special articles of great value to young Clerks, Shorthand Writers, Typists, \&c. Post free, One Shilling.

A sensible book on a small scale on a most important question for Englishmen-How shall we preserve our supremacy as a commercial nation?-The Schoolmaster.

LONDON : I IMPERIAL BUILDINGS, LUDGATE CIRCUS, E.C. 


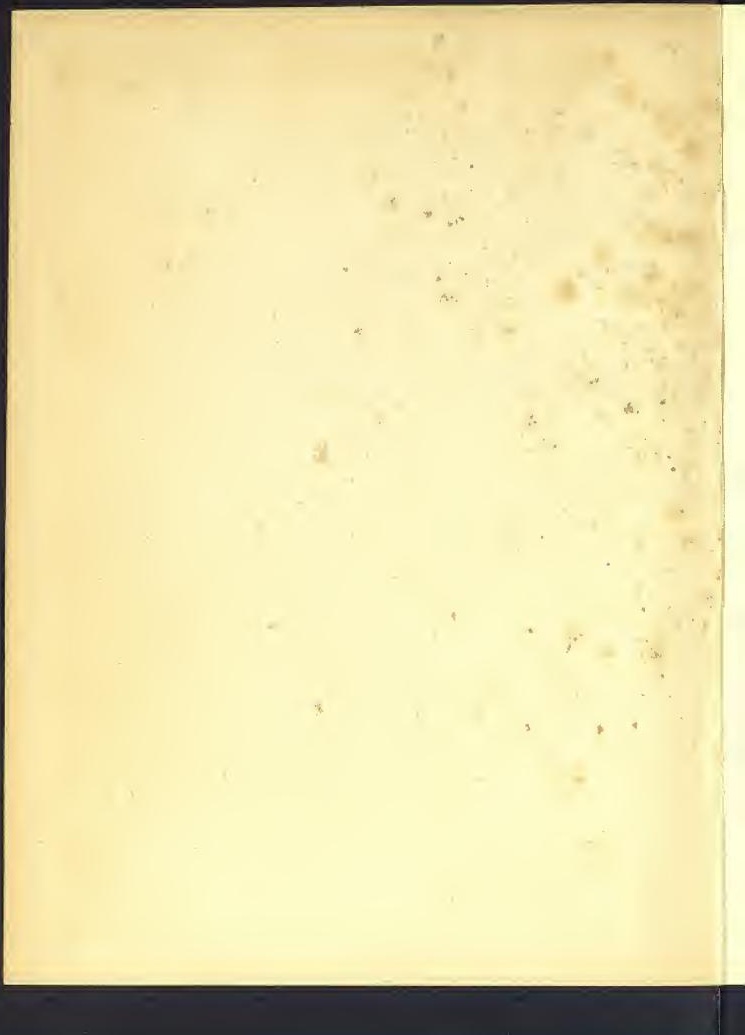





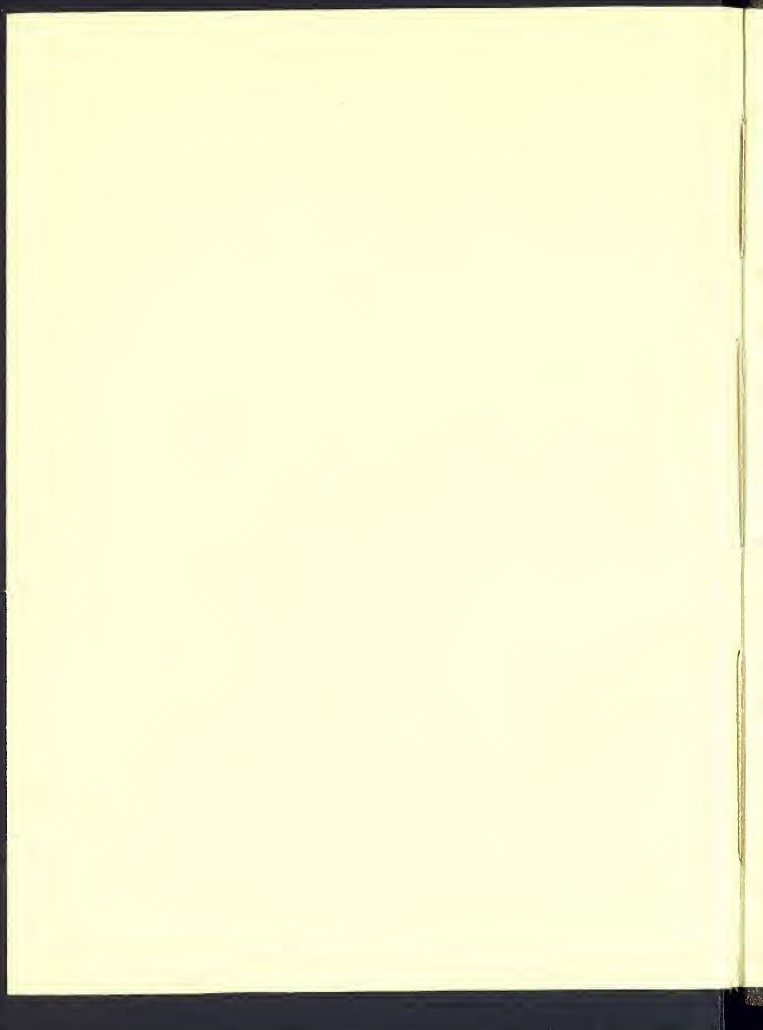




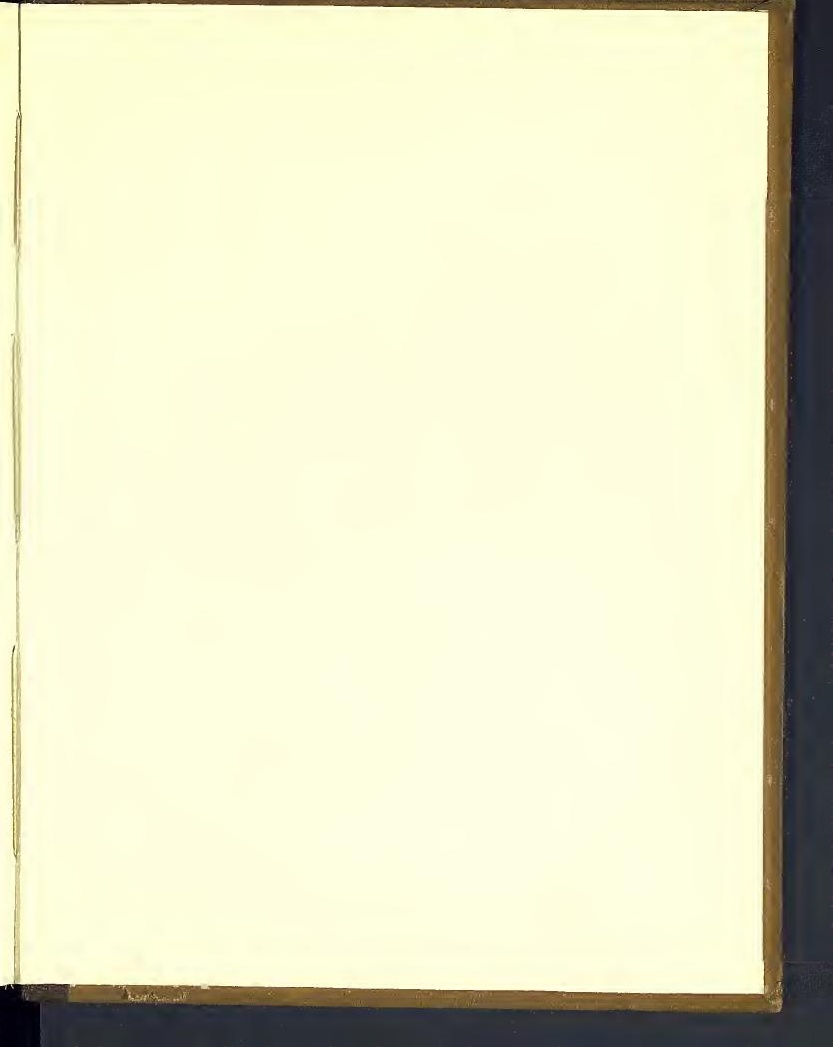




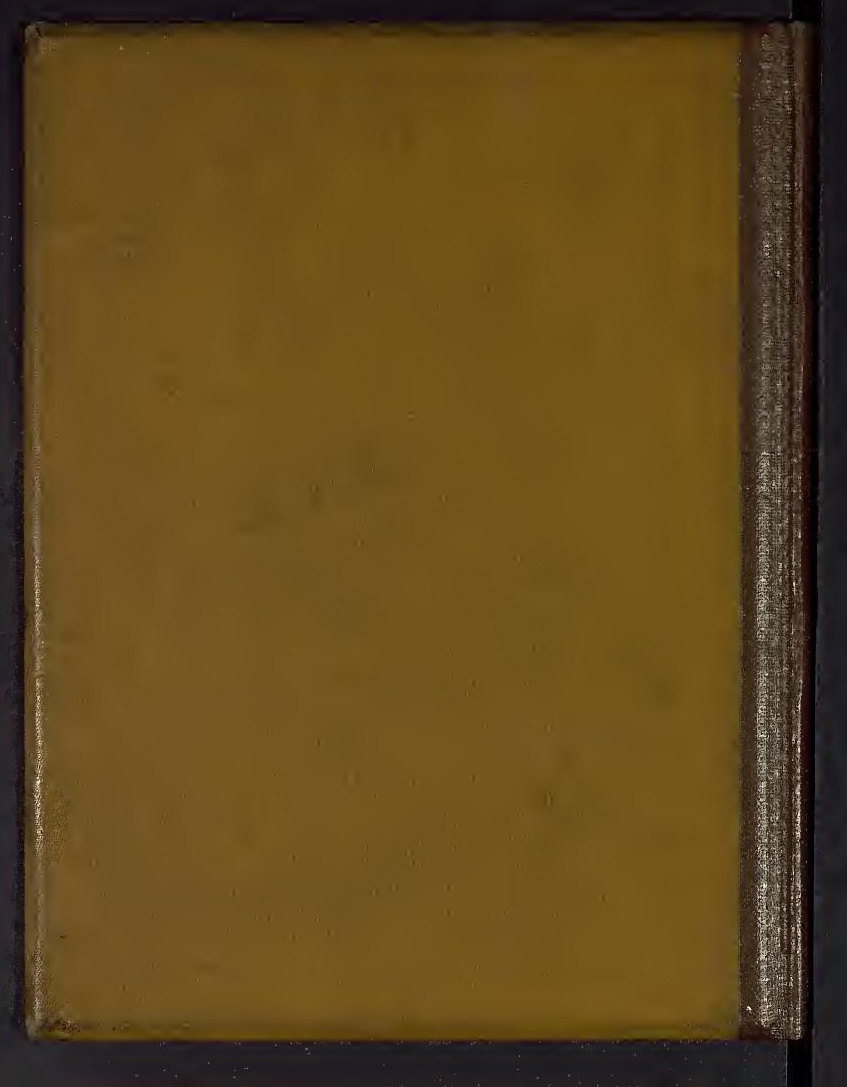



art?

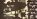
$-4$ $6 y$ s. 63

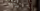

